\title{
A Novel Method for Blunting the Leading Edge of Waverider with Specified Curvature
}

\author{
Xiang Fu, ${ }^{1}$ Jun Liu $\mathbb{D},{ }^{1}$ Feng Ding, ${ }^{1}$ Shengye Wang, ${ }^{1}$ and Tianheng Dou ${ }^{2}$ \\ ${ }^{1}$ College of Aerospace Science and Engineering, National University of Defense Technology, Changsha 410073, China \\ ${ }^{2}$ Xichang Satellite Launch Center, Wenchang 571300, China \\ Correspondence should be addressed to Jun Liu; liujun@nudt.edu.cn
}

Received 15 August 2020; Revised 23 November 2020; Accepted 28 November 2020; Published 21 December 2020

Academic Editor: Jing-Lei Xu

Copyright ( 2020 Xiang Fu et al. This is an open access article distributed under the Creative Commons Attribution License, which permits unrestricted use, distribution, and reproduction in any medium, provided the original work is properly cited.

\begin{abstract}
An ideal waverider has an infinite sharp leading edge, which causes difficulty for manufacture and aerothermal protection. Therefore, the leading edge of the waverider must be blunted. For this purpose, a parametric method for blunting the leading edge of the waverider is proposed here, which can fulfill the goals of setting a leading-edge blunt radius, achieving geometric continuity, and realizing the parametric design. First is the blunting procedure of the proposed method incorporating the construction of two-dimensional blunt curves and the integration of these curves on a three-dimensional waverider configuration. Second, waveriders blunted with different geometric continuities are built with corresponding computing grids generated. Numerical methods are then introduced and validated by the benchmark cases. Finally, results from these blunted configurations are presented and compared in terms of their geometric and flow characteristics. It shows that the proposed method has a better performance in the head region of the waverider and is thereby more suitable for the practical design.
\end{abstract}

\section{Introduction}

The waverider constitutes one of the most promising configurations for hypersonic flight owing to its superior aerodynamic performance and thus finds applications in various fields. Such a configuration in general is analytically designed via streamline tracing in a pregenerated or preselected supersonic/hypersonic flow field that contains the shock wave, thereby incorporating an infinitely sharp leading edge with the shock wave attached. Owing to this, the high-pressure stream behind the shock wave is restricted under the waverider and the high lift-to-drag ratio is consequently achieved, which is crucial in the hypersonic flight.

Since the waverider was first invented in 1959 [1], efforts has been made to improve its performance and adaptability. As a result, various design methods and strategies have been proposed. These investigations are related to three major issues, that is, the design of basic flow fields, the parameteri- zation and optimization, and the remodel design. The first concerns designing a single flow field or assembling multiple flow fields. Research objects of the former include flows over wedges $[2,3]$, cones [4-8], constricting ducts [9], and other three-dimensional base bodies $[10,11]$. For the latter, parts from similar flow fields are assembled to achieve a larger design space. In the osculating methods [12-15], parts of flow fields are combined in the spanwise direction. And the multistage compression waverider [16] is built on multiple conical flow fields, which are in the longitudinal arrangement. As for the second issue, it is common to parameterize the waverider by the characteristic profile curves, which include the upper/lower surface profile curve (USPC/LSPC), the leading edge profile curve (LEPC) or its projection, the shock wave profile curve (SWPC), and the hybrid design of these curves $[17,18]$. Based on the parameterization, we can proceed with the optimization of the waverider. The majority of research focuses on the improvement of the lift- 


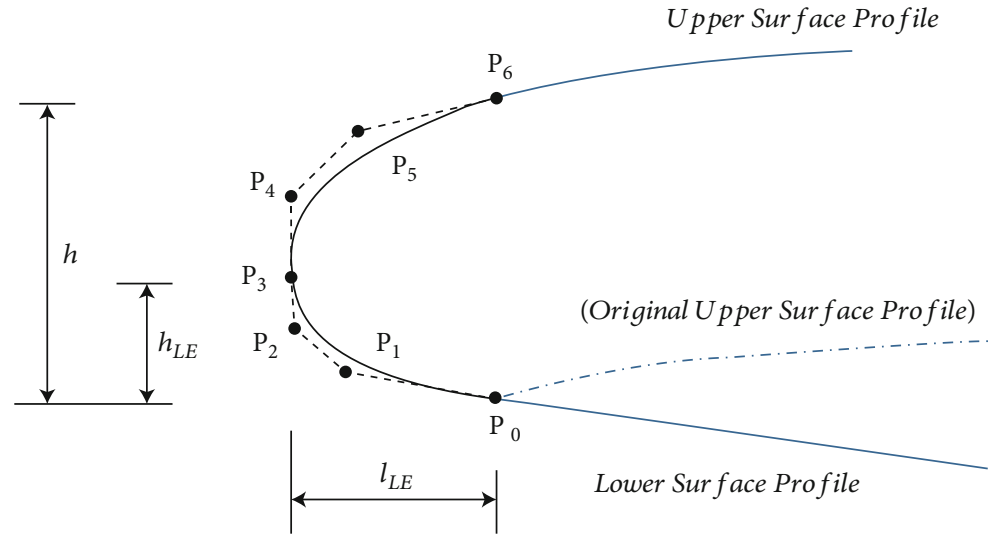

FIGURE 1: Illustration of key points on the blunt curves.

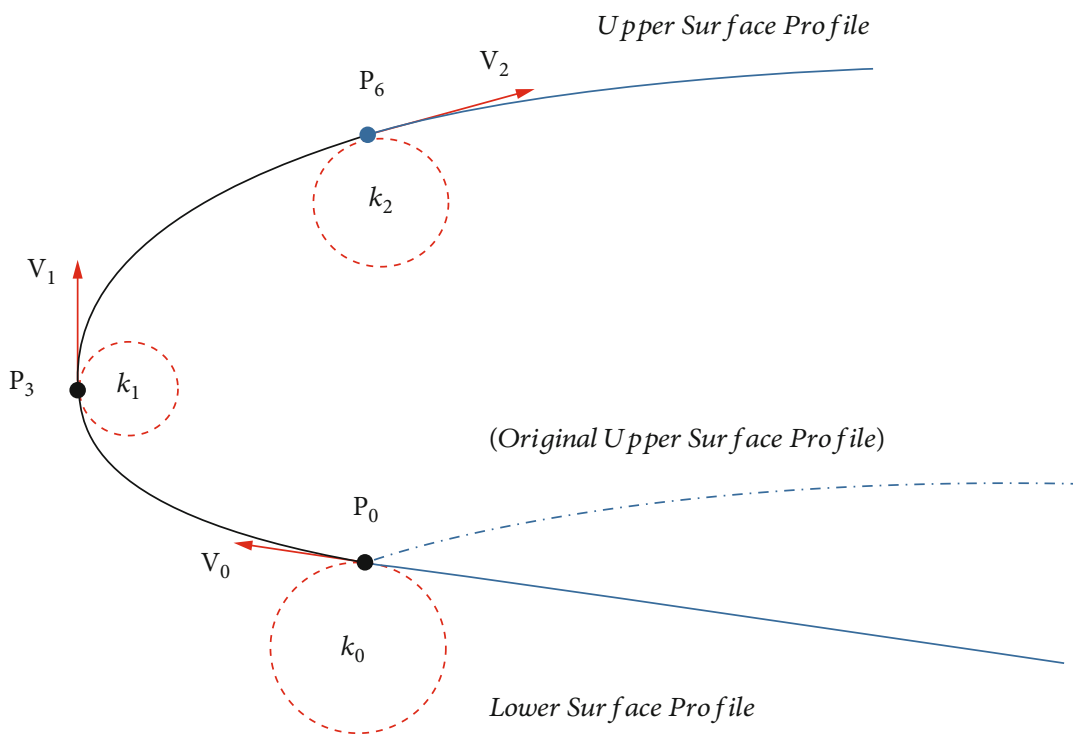

FIGURE 2: Illustration of interpolation conditions on the blunt curves.

to-drag ratio $[19,20]$, while the interests of the community also involve the mission-oriented optimization [21, 22] and the multiobject optimization [23]. The third theme focuses on modifying the geometry of the ideal waverider for realistic purposes. For instance, two waveriders are assembled to get a better wide-speed-range performance [24]; the outer wings are installed on the waverider to improve the low-speed performance [25]. Furthermore, a creative example is to remodel the design principle of characteristic profile curves to construct an airframe/inlet integrated waverider [26]. As the waverider has been extensively researched to this date, it is chosen for several practical hypersonic flight projects [27-29]. Nevertheless, some of the practical considerations proposed in Ref. [30] still needs close attention to further the application of the waverider in practice.

When compared with blunt vehicles like the space shuttle, the sharp leading edge of the ideal waverider makes it unqualified for hypersonic flight. Therefore, the sharp leading edge must be blunted in practice for manufacturability improvement, aerothermal protection, and some handling concerns. Two major aspects have been actively pursued in various blunting methods. In one aspect, the sharp leadingedge geometry is modified by adding or removing the material $[30,31]$ with a special focus on the volume of the waverider. Specifically, while the former lifts the upper surface by separating it from the lower one to preserve the planform of the waverider and increase its volume, the latter truncates the sharp leading edge until a wanted blunt geometry is achieved. The other aspect concerns the choice of blunt curves that include simple ones like circular and elliptical arcs and parametric ones like Bézier curves [32] and rational Bézier curves [33]. The employment of either circular or elliptical arcs can explicitly specify the leading-edge curvature but causes geometric discontinuity at the connection of the blunted part and the original geometry. In contrast, when a single parametric curve is adopted, the higher-order geometric continuity is realized, yet without the blunt radius at the leading-edge point being directly specified. Moreover, 


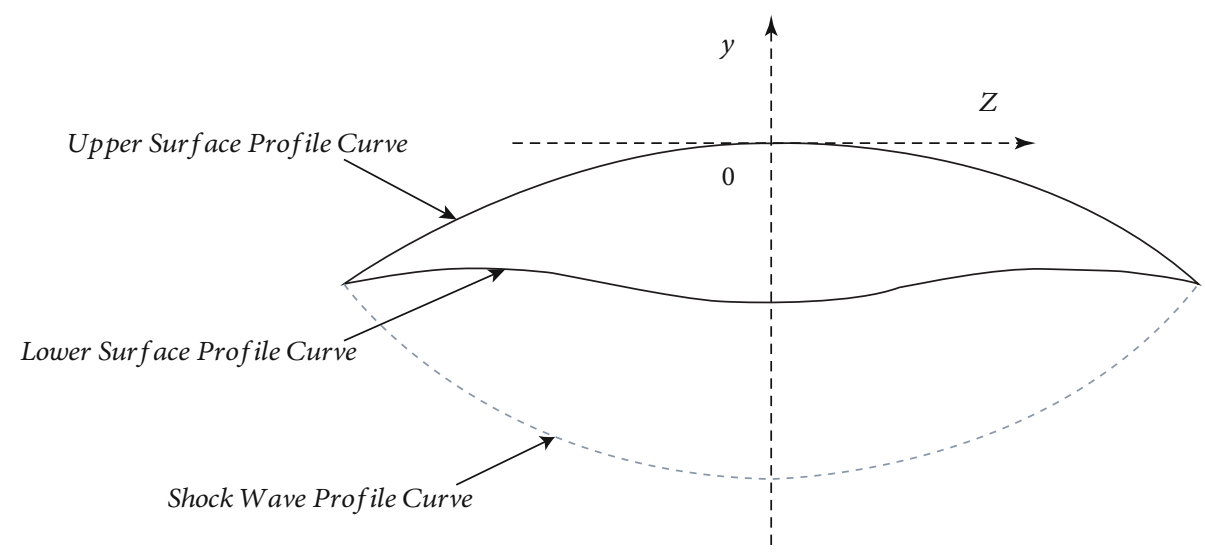

Figure 3: Control curves of an OCD waverider on the base plane.

TABLE 1: Design parameters of the compression surface of sharp waveriders.

\begin{tabular}{lcccc}
\hline Parameters & $L(\mathrm{~mm})$ & $W(\mathrm{~mm})$ & $\mathrm{Ma}$ & $\beta\left(^{\circ}\right)$ \\
\hline Values & 2100.0 & 960.0 & 8.0 & 9.0 \\
\hline
\end{tabular}

in addition to these two aspects, the effects of different bluntness on the performance of the waverider have also been studied [34]. It shows that the heat-transfer rate at the stagnation point varies inversely with the square root of the head blunt radius, while the lift-to-drag ratio inversely with the head blunt radius $[35,36]$. To accommodate the variation of thermal load at different positions and to reduce aerodynamic losses, a method with the nonuniform blunt radius is proposed and studied [37].

To pursue this line of research, this paper is aimed at developing an efficient method based on parametric curves to generate the blunted waverider configuration. The proposed method mainly concerns the design of the blunt curve and involves two cubic Bézier curves to construct the blunted leading edge. Being tentatively viewed as an extension of the method using a single Bézier curve, this method can fulfill the goals of setting the leading-edge blunt radius, achieving second-order geometric continuity, and realizing parametric design, which cannot be fully accomplished by its counterparts. The design approach in detail is described in Section 2 , and physical models and numerical methods are presented in Section 3. The discussion over the influence of different blunting methods on geometric and flow characteristics of waverider is discussed in Section 4.

\section{Method Description}

A typical waverider configuration consists of an upper surface, a compression surface, and a base surface. The longitudinal cross-section of an ideal waverider configuration can be viewed as a forward wedge-like geometry, which allows for parametric curves to be used to generate a curved blunt leading-edge shape [33]. An outline of the proposed blunting method in this paper can be divided into two phases: first, use two cubic Bézier curves to fix the shape of the leading edge for the two-dimensional case; secondly, extending the aforementioned process alongside the spanwise direction to realize the integration on a three-dimensional waverider configuration. The adding-material strategy is adopted in this paper, while it does not influence the applicability of this method with the removing-material strategy.

2.1. Construction of 2D Leading Edge. Two cubic Bézier curves are used in the blunting procedure at the longitudinal section of the waverider. As shown in Figure 1, the upper surface profile is vertically separated from the lower for a distance of $h$. The original leading point is split into two new endpoints, namely, $\mathbf{P}_{\mathbf{0}}$ and $\mathbf{P}_{\mathbf{6}}$. The original wedge-like geometry is blunted and replaced with two cubic Bézier curves $\mathbf{P}_{\mathbf{0}} \mathbf{P}_{\mathbf{3}}$ and $\mathbf{P}_{\mathbf{3}} \mathbf{P}_{\mathbf{6}}$. The new leading-edge point at this section is reset to $\mathbf{P}_{3}$, which has a relative horizontal distance $l_{L E}$ and a relative vertical distance $h_{L E}$ to $\mathbf{P}_{\mathbf{0}}$, the original leading point.

Solving a cubic Bézier curve from the interpolation conditions is referred to as the geometric Hermite interpolation (GHI) [38] problem. The interpolation conditions here are the unit tangent vector and the signed curvature (see Figure 2 for all the involved conditions). The unit tangent vectors $\mathbf{v}_{\mathbf{0}}$ and $\mathbf{v}_{\mathbf{2}}$ depend on the geometry of the original waverider geometry, so it is for the signed curvatures $k_{0}$ and $k_{2}$. Nevertheless, the unit tangent vector $\mathbf{v}_{\mathbf{1}}$ is fixed to vertical upward, while the signed curvature at $\mathbf{P}_{\mathbf{3}}$ is valued artificially.

To be specific, the curve $\mathbf{P}_{\mathbf{0}} \mathbf{P}_{\mathbf{3}}$ is chosen to illustrate the solution procedure of the cubic Bézier curve. $\mathbf{P}_{\mathbf{3}} \mathbf{P}_{\mathbf{6}}$ can be solved in the same manner. Note that the endpoints $\mathbf{P}_{\mathbf{0}}$ and $\mathbf{P}_{3}$ are already specified, while the control points $\mathbf{P}_{\mathbf{1}}$ and $\mathbf{P}_{\mathbf{2}}$ are to be solved.

The positions of $\mathbf{P}_{\mathbf{1}}$ and $\mathbf{P}_{\mathbf{2}}$ are defined by

$$
\begin{aligned}
& \mathbf{P}_{1}=\mathbf{P}_{0}+\delta_{0} \mathbf{v}_{0}, \\
& \mathbf{P}_{2}=\mathbf{P}_{3}-\delta_{1} \mathbf{v}_{1},
\end{aligned}
$$

and a system of quadratic equations is constructed for solving $\delta[38]$, which is written as 


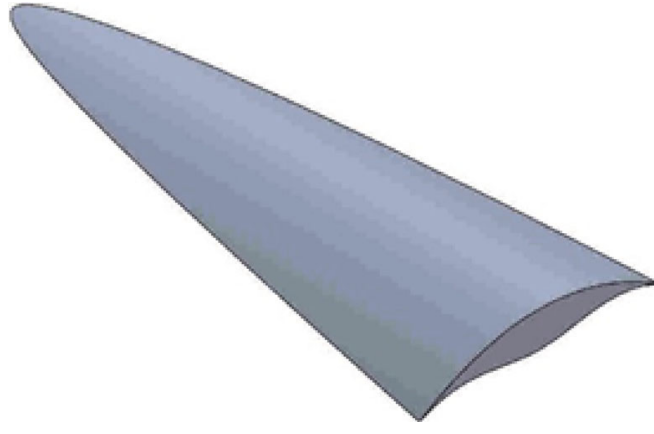

(a)

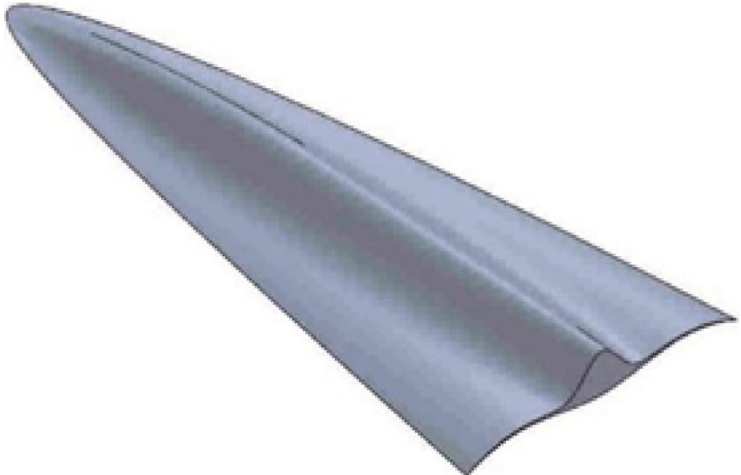

(b)

FIGURE 4: Isometric views of two sharp waveriders with different upper surfaces: (a) WR1; (b) WR2.

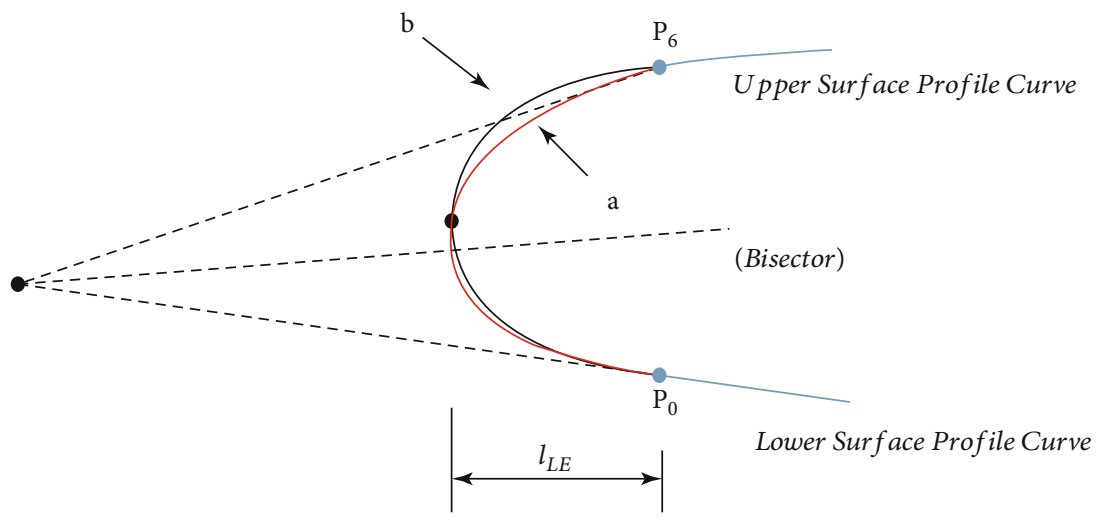

FIGURE 5: Difference in the position of the new leading-edge point: (a) $G^{0}$ method (black); (b) $G^{2}$ method (red).

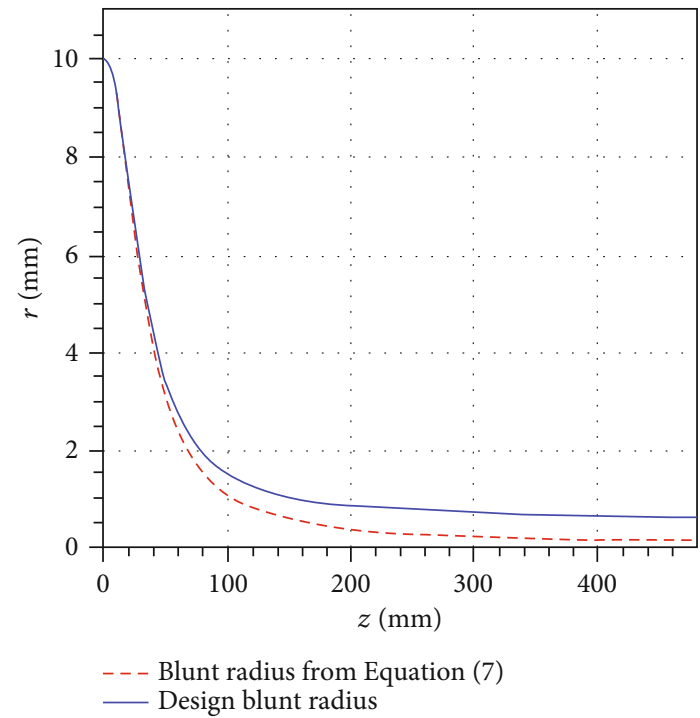

FIGURE 6: Variations of blunt radius alongside the spanwise direction.

$$
\begin{aligned}
& \left(\mathbf{v}_{\mathbf{0}} \times \mathbf{v}_{\mathbf{1}}\right) \delta_{0}=\left(\mathbf{d} \times \mathbf{v}_{\mathbf{1}}\right)-\frac{3}{2} k_{1} \delta_{1}^{2}, \\
& \left(\mathbf{v}_{\mathbf{0}} \times \mathbf{v}_{\mathbf{1}}\right) \delta_{1}=\left(\mathbf{v}_{\mathbf{0}} \times \mathbf{d}\right)-\frac{3}{2} k_{0} \delta_{0}^{2},
\end{aligned}
$$

in which $\mathbf{d}=\mathbf{P}_{\mathbf{3}}-\mathbf{P}_{\mathbf{0}}$.

When blunting the leading edge of waverider, the results of $\mathbf{v}_{\mathbf{0}} \times \mathbf{v}_{\mathbf{1}}, \mathbf{d} \times \mathbf{v}_{\mathbf{1}}$, and $\mathbf{v}_{\mathbf{0}} \times \mathbf{d}$ are apparently equal to zero in no case, while $k_{0}$ and $k_{2}$ are likely to be equal to or proximate to zero. In this case, Equation (2) can be simplified by introducing the new parameters $\rho$ and $S$, which are defined by

$$
\begin{gathered}
\delta_{0}=\rho_{0} \frac{\mathbf{d} \times \mathbf{v}_{\mathbf{1}}}{\mathbf{v}_{\mathbf{0}} \times \mathbf{v}_{\mathbf{1}}}, \\
\delta_{1}=\rho_{1} \frac{\mathbf{v}_{\mathbf{0}} \times \mathbf{d}}{\mathbf{v}_{\mathbf{0}} \times \mathbf{v}_{\mathbf{1}}}, \\
S_{0}=\frac{3}{2} \frac{k_{0}\left(\mathbf{d} \times \mathbf{v}_{\mathbf{1}}\right)^{2}}{\left(\mathbf{v}_{\mathbf{0}} \times \mathbf{d}\right)\left(\mathbf{v}_{\mathbf{0}} \times \mathbf{v}_{\mathbf{1}}\right)^{2}}, \\
S_{1}=\frac{3}{2} \frac{k_{1}\left(\mathbf{v}_{\mathbf{0}} \times \mathbf{d}\right)^{2}}{\left(\mathbf{d} \times \mathbf{v}_{\mathbf{1}}\right)\left(\mathbf{v}_{\mathbf{0}} \times \mathbf{v}_{\mathbf{1}}\right)^{2}} .
\end{gathered}
$$

Substituting Equations (3) and (4) into Equation (2) yields an equivalent system 


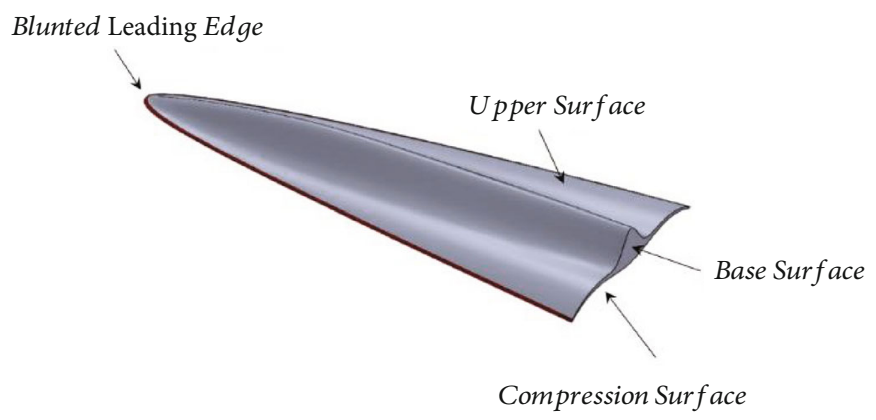

FiguRE 7: Isometric view of the WR2-G ${ }^{2}$ configuration.

TABLE 2: Experimental conditions of the two validation cases.

\begin{tabular}{lccccc}
\hline Cases & $\mathrm{Ma}$ & $\operatorname{Re}\left(10^{6} \times \mathrm{m}^{-1}\right)$ & $\alpha\left(^{\circ}\right)$ & $P_{0}(\mathrm{MPa})$ & $T_{0}(\mathrm{~K})$ \\
\hline VC1 & 8.02 & 19.8 & 0 & 8.5 & 720 \\
VC2 & 10.02 & 2.2 & 0 & 6.9 & 1457 \\
\hline
\end{tabular}

$$
\begin{aligned}
& \rho_{0}=1-S_{1} \rho_{1}^{2}, \\
& \rho_{1}=1-S_{0} \rho_{0}^{2} .
\end{aligned}
$$

By solving Equation (5), the parameters $\delta$ are obtained, and the cubic Bézier curve $\mathbf{P}_{\mathbf{0}} \mathbf{P}_{\mathbf{3}}$ is constructed. The value of $S_{0}$ determines the solution of Equation (5). When $S_{0}$ is nonzero, Equation (5) is transformed into a quartic polynomial equation of $\rho_{0}$ as Equation (6), the roots of which are equal to the eigenvalues of its companion matrix. As there would be multiple real roots, the affine invariants $\lambda$ and $\mu$ [39] are used to check the shape of the cubic Bézier curve.

$$
\rho_{0}^{4}-\frac{2}{S_{0}} \rho_{0}^{2}+\frac{2}{S_{0}^{2} S_{1}} \rho_{0}+\frac{S_{1}-1}{S_{0}^{2} S_{1}}=0
$$

2.2. Integration on $3 D$ Waverider Geometry. When integrating the two-dimensional blunt curve mentioned earlier in the three-dimensional configuration, factors to be considered include the adding/removing material method, the direction of blunting curves, the variation of leading-edge radius, etc. The preferred methods are presented in this subsection.

As the adding material method is adopted here, the upper surface of the waverider is separated vertically from the lower one for a distance of $h$. Nevertheless, the transition distance varies alongside the leading edge when the variable blunt radius is considered. Here, $h$ is set to be the function of the spanwise coordinate, namely, $h(z)$. If the method of removing material is chosen, the truncation length varies alongside the leading edge [33], too.

The blunting curve is sketched on the reference plane that is parallel to the symmetry plane and the free stream. The merit lies in the blunt radius front straight to the free stream being directly specified. Besides, the reference plane can also be perpendicular to the leading edge or parallel to the osculating plane [33].
It is important and meaningful to control how the radius of curvature is distributed along the spanwise direction, from the head to the tip. In Ref. [32], Equation (7) is proposed for the off-centerline leading edge radius, $R_{S W}$, which is written as a function of the centerline radius, $R_{C T}$, and the local leading-edge sweep, $\lambda_{S W}$. With this equation, the heating rate at the off-centerline leading-edge position would be the same as the centerline, which makes the most use of the thermal protection system.

$$
R_{S W}=R_{C T}\left(\cos \lambda_{S W}\right)^{2.2} .
$$

The blunt leading edge of the three-dimensional waverider is constructed by lofting all the two-dimensional leading edges, which is implemented through computer-aided design (CAD).

\section{Physical Models and Numerical Methods}

The generation of two sharp waveriders based on the osculating cone-derived (OCD) method [12] is presented in this section. The parameters of the proposed blunting method are described, accompanied by the introduction of the comparable blunting method that uses the elliptical blunt curve. In the second subsection, the numerical methods are illustrated and validated via two benchmark problems.

3.1. Physical Models. When generating an ideal waverider, the compression surface should be given the priority, as it decisively influences the aerodynamic performance of the waverider. Here, the classical OCD method is adopted to generate the lower surface, while the upper surface profile curve (USPC) and the shock wave profile curve (SWPC) are designed as the control curves (see Figure 3). The design parameters include the length $L$, the width $W$, the design Mach number $M a$, and the shock angle $\beta$, which are listed in Table 1. It should be noted that all the waveriders presented in this paper have the same characteristic sizes, which are $2100 \mathrm{~mm}$ in length and $960 \mathrm{~mm}$ in width.

To better investigate the influence of different blunting methods, two waveriders that have the same compression surface yet different upper surfaces are generated. The first waverider whose configuration is referred to as WR1 has a free-stream upper surface. The second waverider named WR2 has a reshaped upper surface to realize a better 


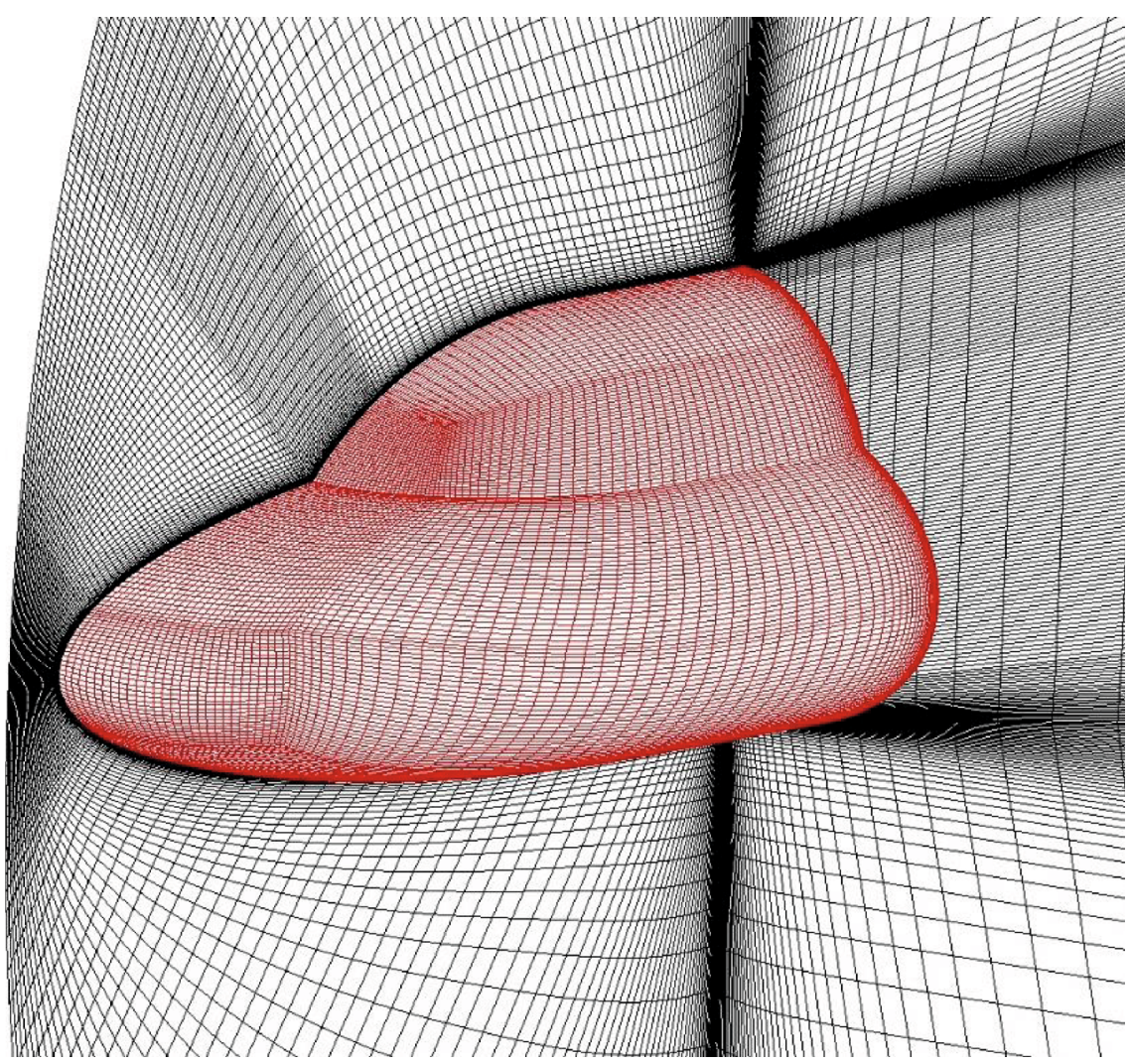

FIGURE 8: Illustration of the structured grid for the two validation cases.

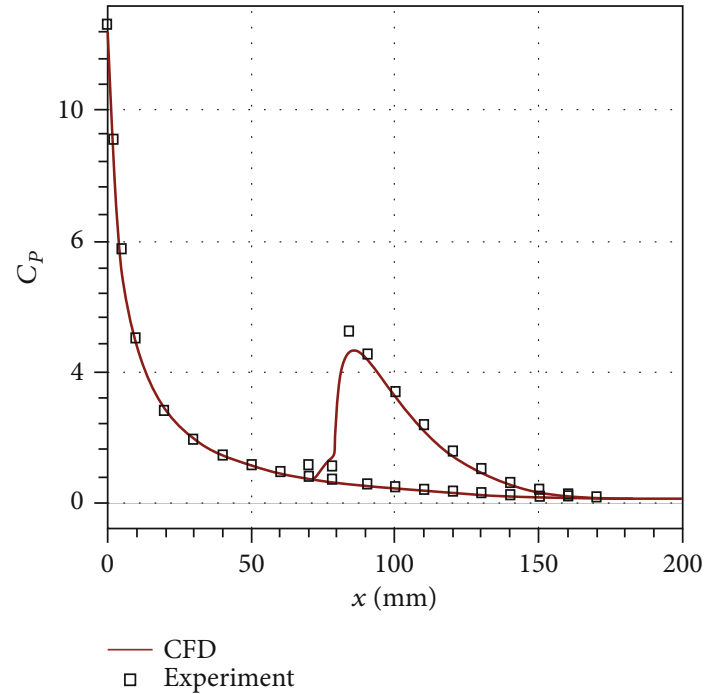

(a)

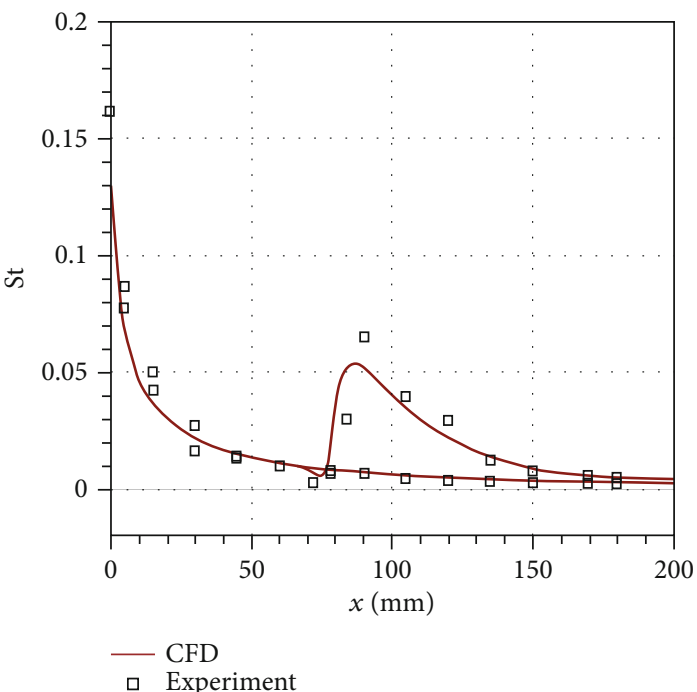

(b)

FIGURE 9: Comparisons between numerical results and experimental data: (a) $C_{P}$ results from VC1; (b) St results from VC2.

TABLE 3: Computational conditions for the blunt waveriders.

\begin{tabular}{lccccc}
\hline Cases & $\mathrm{Ma}$ & $\operatorname{Re}\left(10^{6} \times \mathrm{m}^{-1}\right)$ & $\alpha\left(^{\circ}\right)$ & $P_{0}(\mathrm{MPa})$ & $T_{0}(\mathrm{~K})$ \\
\hline Blunt waveriders & 8.0 & 2.95 & 0 & 11.44 & 3127.77 \\
\hline
\end{tabular}

volumetric characteristic and a higher lift-to-drag ratio. To be specific, while its volume is concentrated to the middle of the waverider, its sides are thinner than the ideal one, just like the HiFIRE-4 vehicle [28]. This kind of design is more demanding on the blunting method than the free-stream surface, as it has a variable geometry characteristic on the leading edge. The two sharp waveriders are shown in Figure 4. 


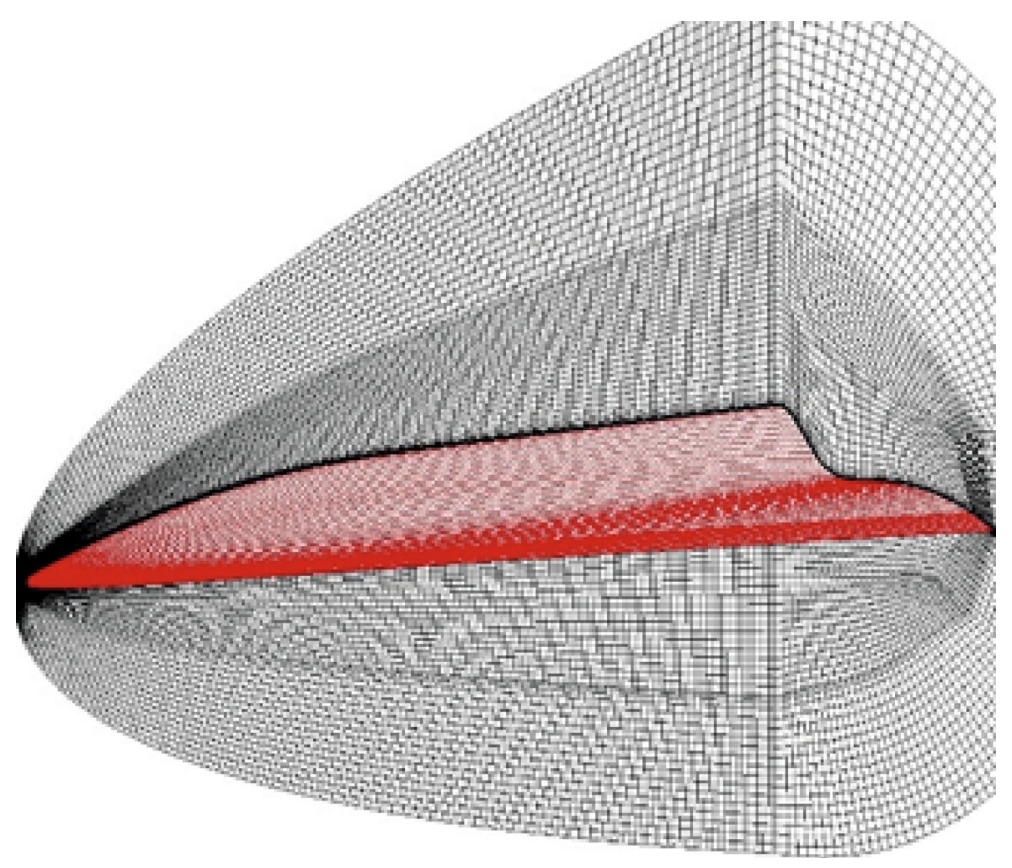

(a)

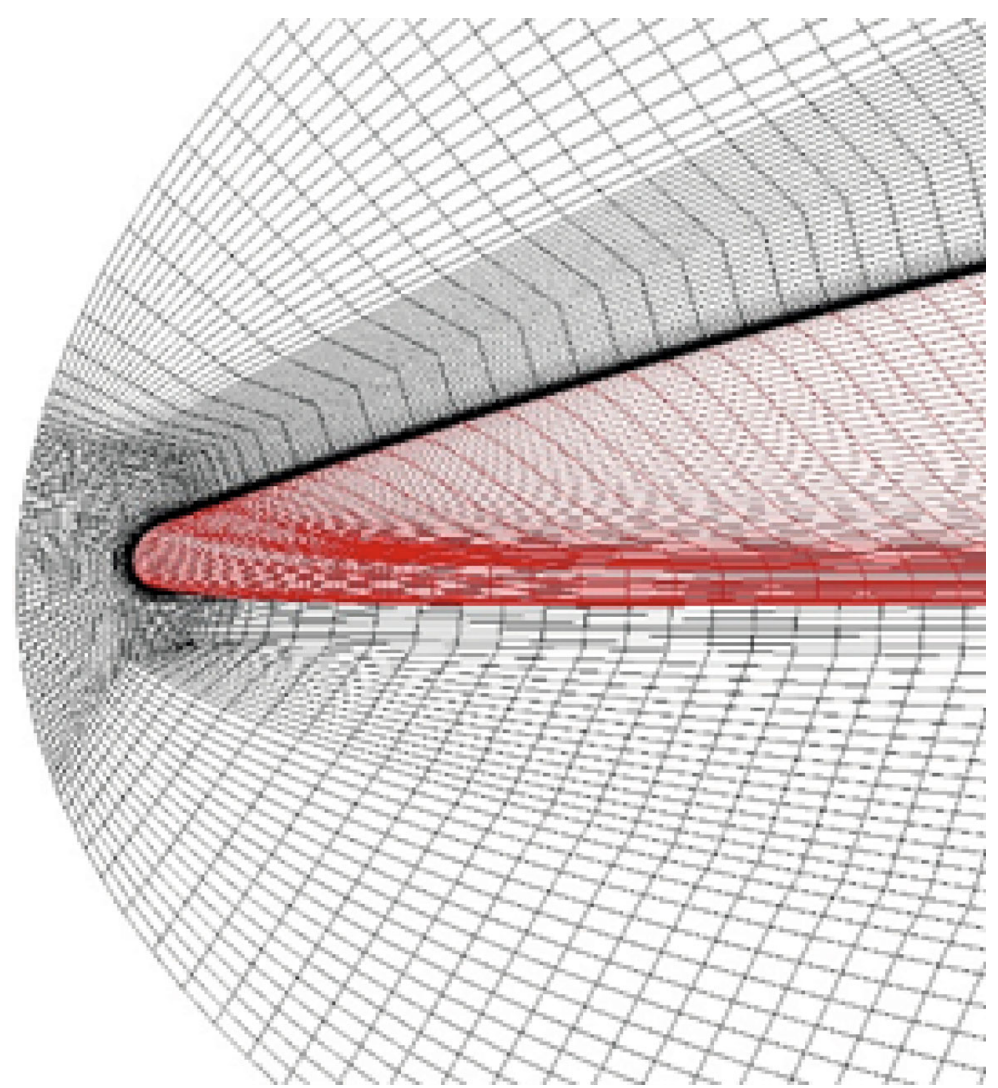

(b)

FIGURE 10: Illustration of the structured grid for WR2-G²: (a) overall view; (b) close-up view on the head. 
TABle 4: Overall geometric characteristics of the blunted waveriders.

\begin{tabular}{lcccc}
\hline Configurations & $S\left(\mathrm{~m}^{2}\right)$ & $S_{B}\left(\mathrm{~m}^{2}\right)$ & $V\left(\mathrm{~m}^{3}\right)$ & $V_{A}\left(\mathrm{~m}^{3}\right)$ \\
\hline WR1 & 2.65 & 0.0709 & 0.0564 & 0.0161 \\
WR2 & 2.69 & 0.0245 & 0.0419 & 0.0157 \\
WR1-G & 2.78 & 0.0808 & 0.0704 & 0.0229 \\
WR1-G & 2.77 & 0.0809 & 0.0705 & 0.0229 \\
WR2-G & 2.84 & 0.0344 & 0.0559 & 0.0213 \\
WR2-G $^{2}$ & 2.83 & 0.0344 & 0.0559 & 0.0213 \\
\hline
\end{tabular}

For the sake of comparison, a blunting method that provides zero-order geometric continuity is introduced. It uses a half elliptical arc to connect the upper and lower surface profiles of the waverider. To be brief, the new blunting method proposed in this paper is referred to as the $G^{2}$ method, while the method concerning the elliptical curve is referred to as the $G^{0}$ method. As for the $G^{0}$ method, its leading-edge point is exactly the vertex of the elliptical arc, and its position is related to the leading-edge radius and the transition distance of the upper surface. The new leading point of the $\mathrm{G}^{2}$ method is placed on the bisector of the tangent lines passing through the two endpoints, as shown in Figure 5.

The blunt radius and the vertical transition distance are set to the same value when blunting waveriders through the two methods. In Figure 6, the blunt radius calculated from Equation (7) and the design variation are demonstrated together. The former is taken as a reference line for the design of the blunt radius. It shows that the design variation ranges from $10 \mathrm{~mm}$ at the center plane to $0.63 \mathrm{~mm}$ at the wingtip.

The WR1 and WR2 configurations are blunted by the $\mathrm{G}^{0}$ and $G^{2}$ methods, respectively. Consequently, four blunted waveriders named WR1-G $G^{0}$ WR1-G ${ }^{2}, W R 2-G^{0}$, and WR2$\mathrm{G}^{2}$ are obtained. It is noted that all four blunted configurations have the same planform and the same distribution of blunt radius. Figure 7 gives the isometric view of the WR2$\mathrm{G}^{2}$ configuration.

3.2. Numerical Methods. The waveriders in this paper are all designed based on the inviscid flow field, and no viscous correction is implemented on these configurations. Therefore, both the inviscid and the viscous calculation are considered when evaluating the performance of waverider by the computational fluid dynamic (CFD) method.

To simulate the viscous flow around the waverider, the three-dimensional Reynolds averaged Navier-Stokes (RANS) equations are solved by the implicit finite volume method (FVM). The governing equations of the mean flow are closed by the shear-stress transport (SST) $k-\omega$ turbulence model, a two-equation model that is popular in both industry and academics. The second-order spatially accurate upwind scheme with the advection upstream (AUSM) splitting approach is employed to split the flux vector. The Courant-FriedrichsLewy (CFL) number is maintained at 0.5 to ensure stability. The convergence is reached if the residuals fall by more than four orders of magnitude, and the difference between the computed inflow and outflow mass flux falls below $0.1 \%$.
The boundary condition of the wall is assumed to be isothermal $\left(T_{w}=300 \mathrm{~K}\right)$ and no-slip. The air is assumed to be a thermally and calorically perfect gas with the viscosity modelled according to the well-known Sutherland law. For the inviscid calculation, the Euler equations are solved in the similar manner as the RANS equations.

Two hypersonic experimental cases [40] are chosen to validate the accuracy of the numerical methods applied in this paper. The first validation case VC1 focuses on measuring the surface pressure of the double ellipsoid, while the second one VC2 concentrates on the measurement of the surface heat flux. The experimental conditions are given in Table 2. $y^{+}$of the first cell height and the cell Reynolds number $R e_{\text {grid }}$ are used as two criteria to guide the generation of the waverider grid: $y^{+}$should be set to smaller than 1 for the simulation of force [41]; $R e_{\text {grid }}$ should be set to smaller than 10 for the simulation of heat flux [42]. Thus, a set of multiblock structured grids is generated for the numerical simulation. As depicted in Figure 8, it has 2,078,848 cells and a first cell height of $0.005 \mathrm{~mm}$. For the VC1 case, the maximum value of $y^{+}$is 1.10 , while $R e_{\text {grid }}$ for the VC2 case is 1.45 .

$$
\begin{gathered}
y^{+}=\frac{\rho_{w} u_{\tau} \Delta y}{\mu_{w}}, \\
R e_{\text {grid }}=\frac{\rho_{\infty} v_{\infty} \Delta y}{\mu_{\infty}} .
\end{gathered}
$$

In this paper, the pressure coefficient $C_{P}$ and the Stanton number $S t$ are employed as normalizations of the surface pressure and the surface heat flux, respectively, for further comparison. The definitions of $C_{P}$ and $S t$ are expressed in

$$
\begin{gathered}
C_{P}=\frac{p-p_{\infty}}{(1 / 2) \rho_{\infty} v_{\infty}^{2}}, \\
S t=\frac{q}{\left(T_{w}-T_{\infty}\right) \rho_{\infty} v_{\infty} c_{p \infty}} .
\end{gathered}
$$

The results of the numerical simulation are compared with the experimental data (see Figure 9 for details). While there exists a discrepancy, the changing trends of numerical results are consistent with the experimental data, which validates the numerical methods applied in this paper.

When it comes to the blunted waveriders, the simulated flight is executed at $\mathrm{Ma}=8.0$ and $H=30 \mathrm{~km}$ with an angle of attack of $0^{\circ}$, which is shown in Table 3. The computational grids for the four blunted waveriders have 1,529,616 cells, with its first cell height of grids set to $0.001 \mathrm{~mm}$, which corresponds to $y^{+}=0.55$ and $R e_{\text {grid }}=3.68$. Figure 10 gives the overall view and the close-up view of the WR2-G $\mathrm{G}^{2}$ mesh.

\section{Results and Discussion}

In this section, the influence of different blunting methods on the characteristics of waveriders is studied and discussed, including geometric characteristics and flow characteristics. 


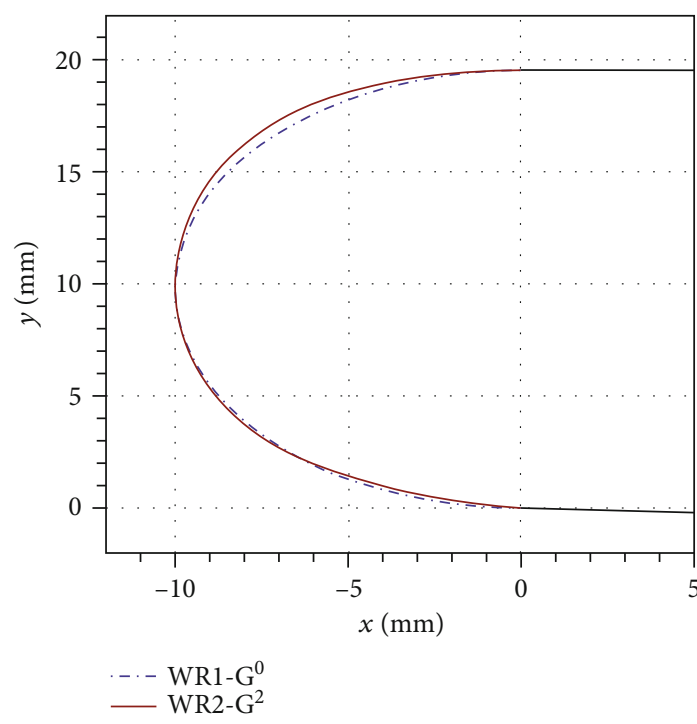

(a)

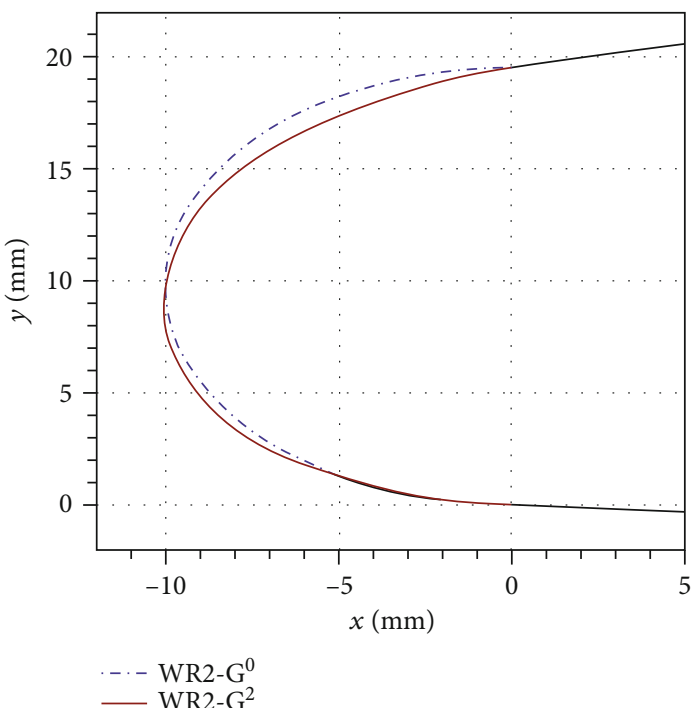

(b)

FIGURE 11: Blunting curves on the central plane of waveriders: (a) blunting curves from WR1-G $\mathrm{G}^{0}$ and WR1-G ${ }^{2}$; (b) blunting curves from WR2-G ${ }^{0}$ and WR2-G ${ }^{2}$.

TABLE 5: Overall aerodynamic performances of the blunted waveriders.

\begin{tabular}{|c|c|c|c|c|c|c|}
\hline \multirow{2}{*}{ Cases } & \multicolumn{3}{|c|}{ Inviscid calculation } & \multicolumn{3}{|c|}{ Viscous calculation } \\
\hline & $C_{D} \times 10^{-2}$ & $C_{L} \times 10^{-2}$ & $L / D$ & $C_{D} \times 10^{-2}$ & $C_{L} \times 10^{-2}$ & $L / D$ \\
\hline WR1 & 0.0690 & 1.17 & 16.96 & 0.270 & 1.20 & 4.44 \\
\hline WR2 & 0.113 & 1.54 & 13.63 & 0.296 & 1.53 & 5.16 \\
\hline WR1-G & 0.171 & 1.13 & 6.61 & 0.389 & 1.14 & 2.92 \\
\hline WR1-G ${ }^{2}$ & 0.172 & 1.15 & 6.68 & 0.391 & 1.15 & 2.95 \\
\hline WR $2-\mathrm{G}^{0}$ & 0.208 & 1.45 & 6.97 & 0.405 & 1.43 & 3.53 \\
\hline WR2-G ${ }^{2}$ & 0.211 & 1.47 & 6.97 & 0.406 & 1.45 & 3.58 \\
\hline
\end{tabular}



-. - WR1-G

- WR1-G

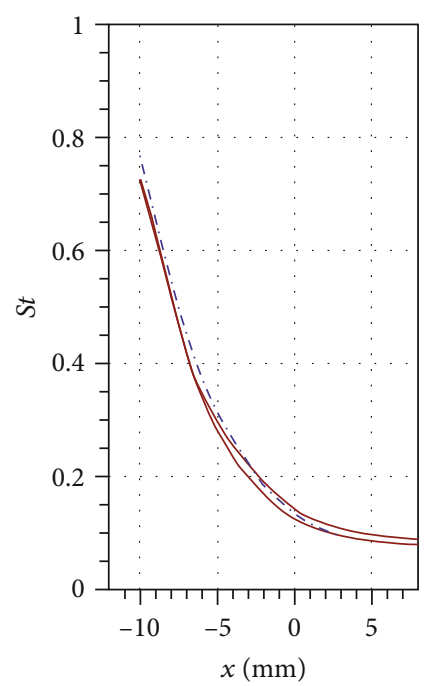

(a)
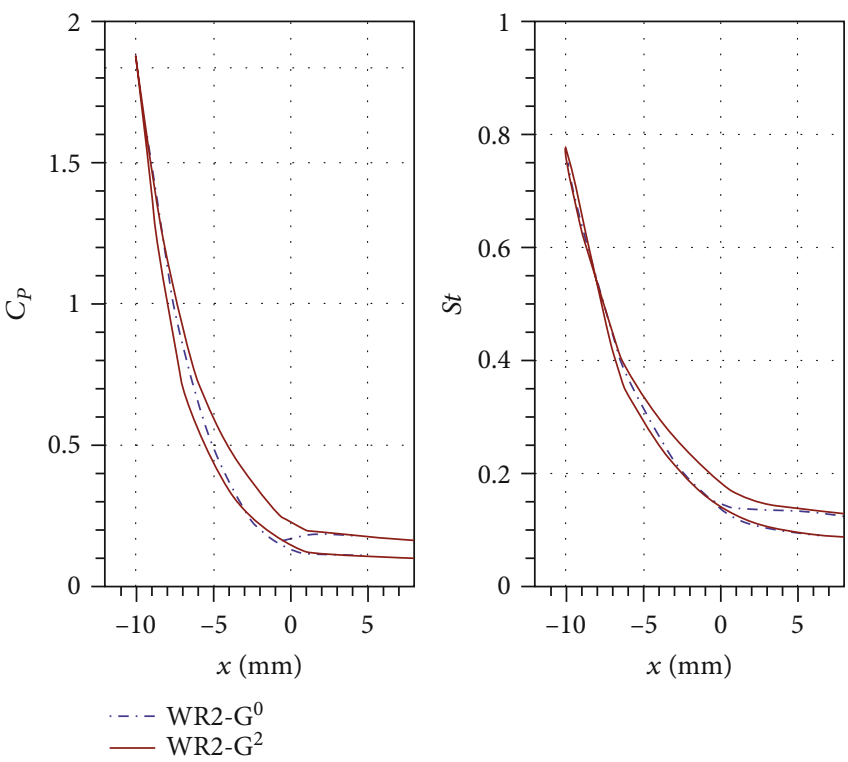

(b)

FIGURE 12: Surface characteristics on the central blunt curve: (a) comparison between WR1-G ${ }^{0}$ and WR1-G ${ }^{2}$; (b) comparison between WR2$\mathrm{G}^{0}$ and WR2-G ${ }^{2}$. 


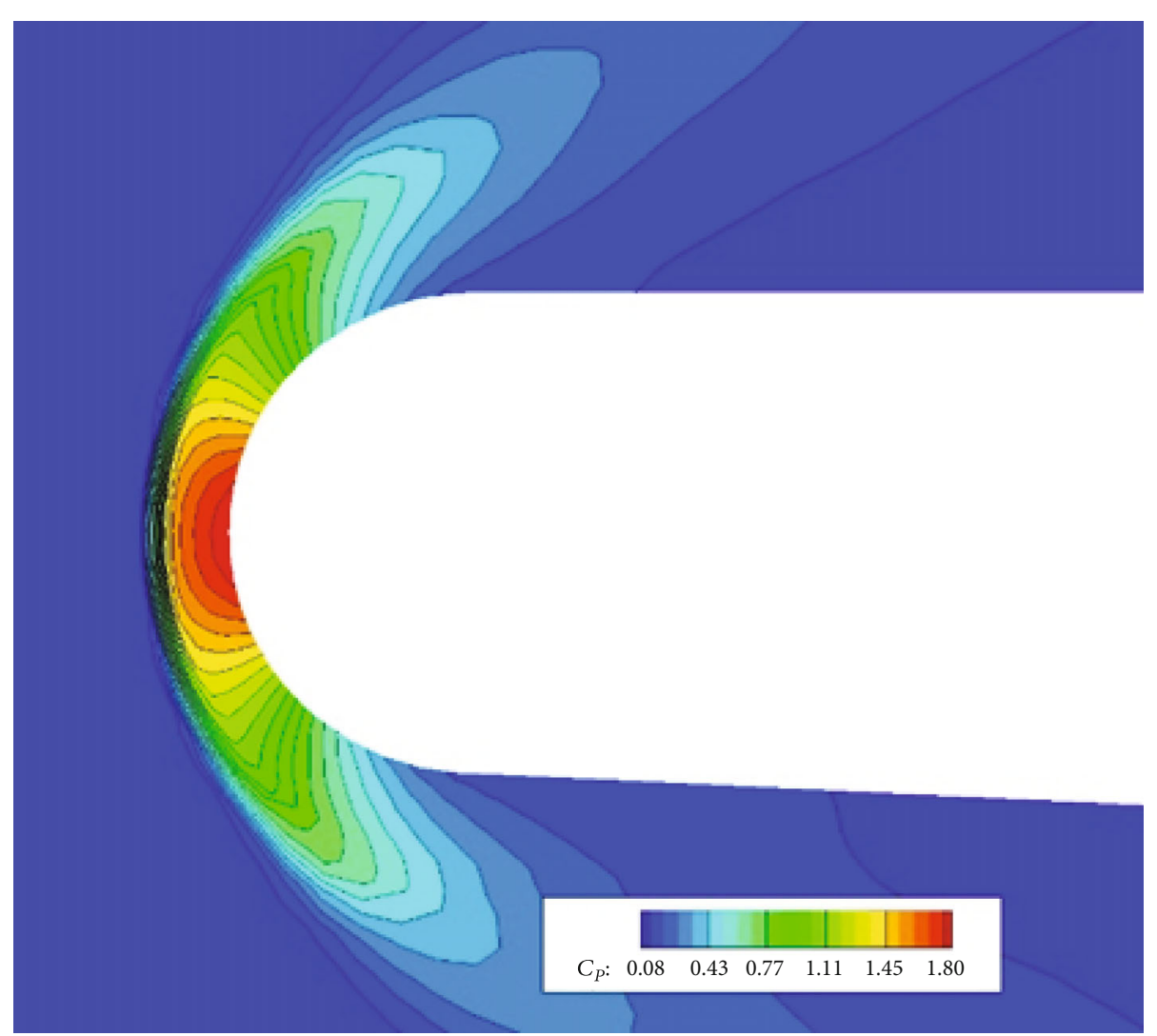

(a)

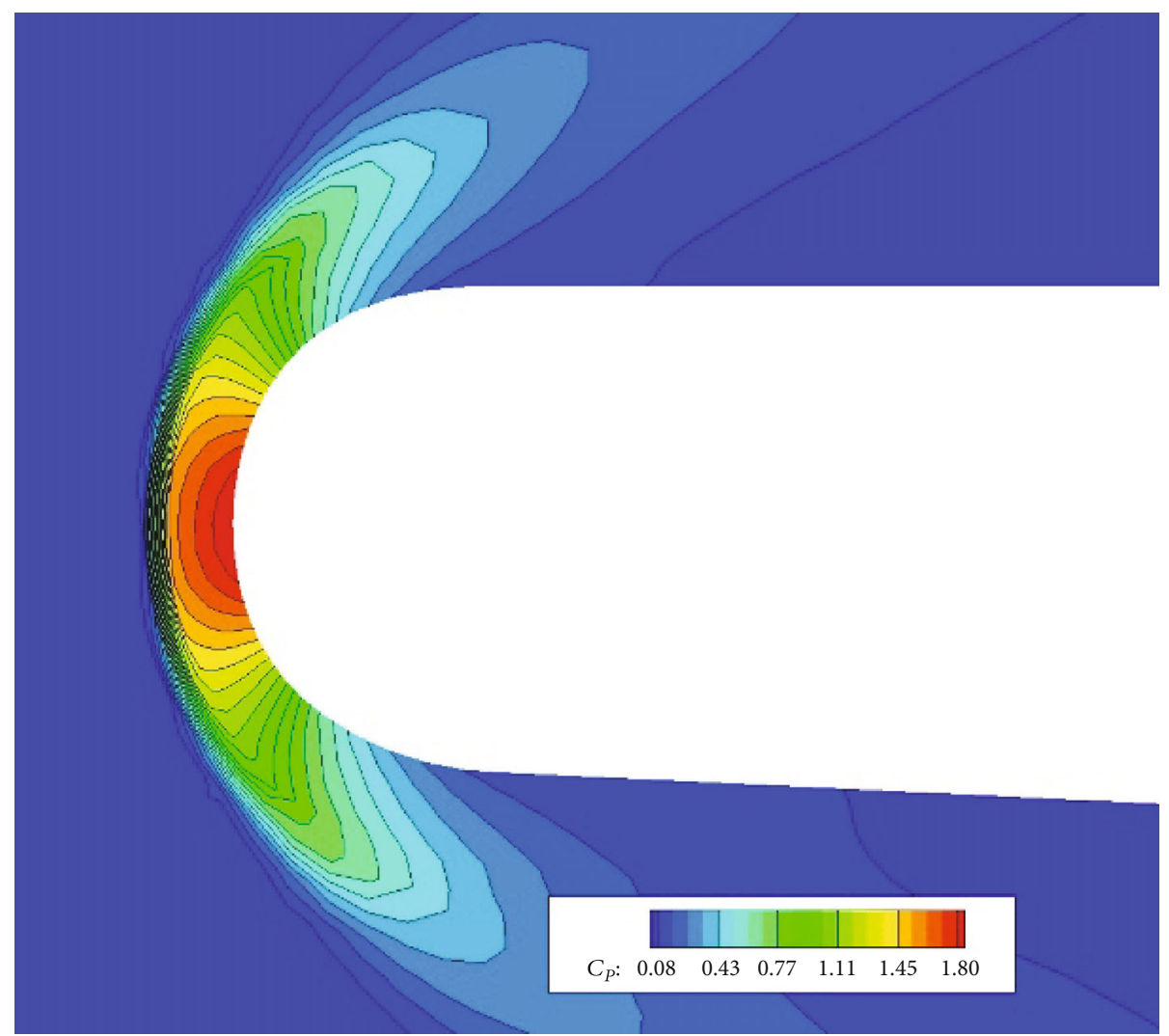

(b)

FIgUre 13: Continued. 


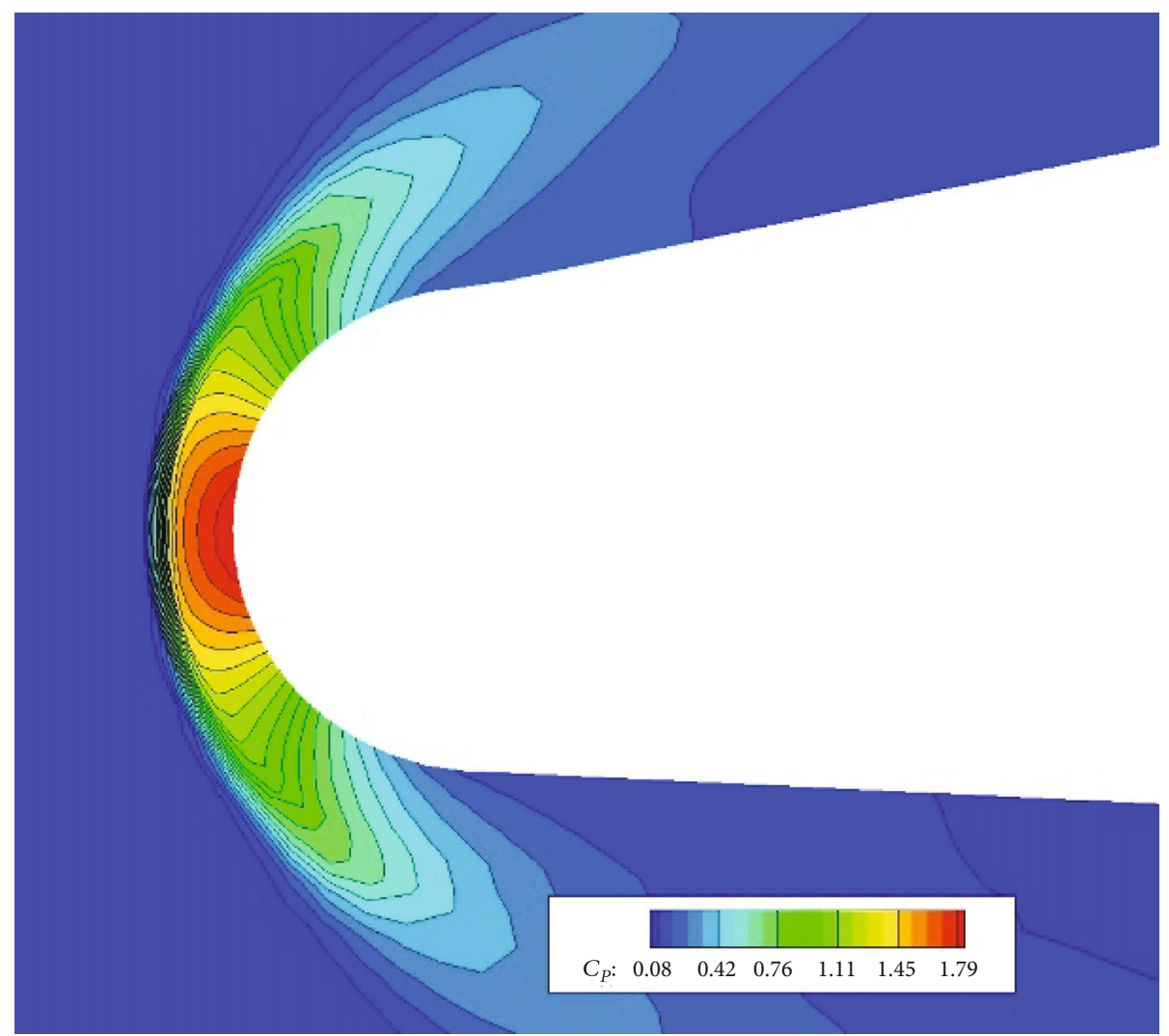

(c)

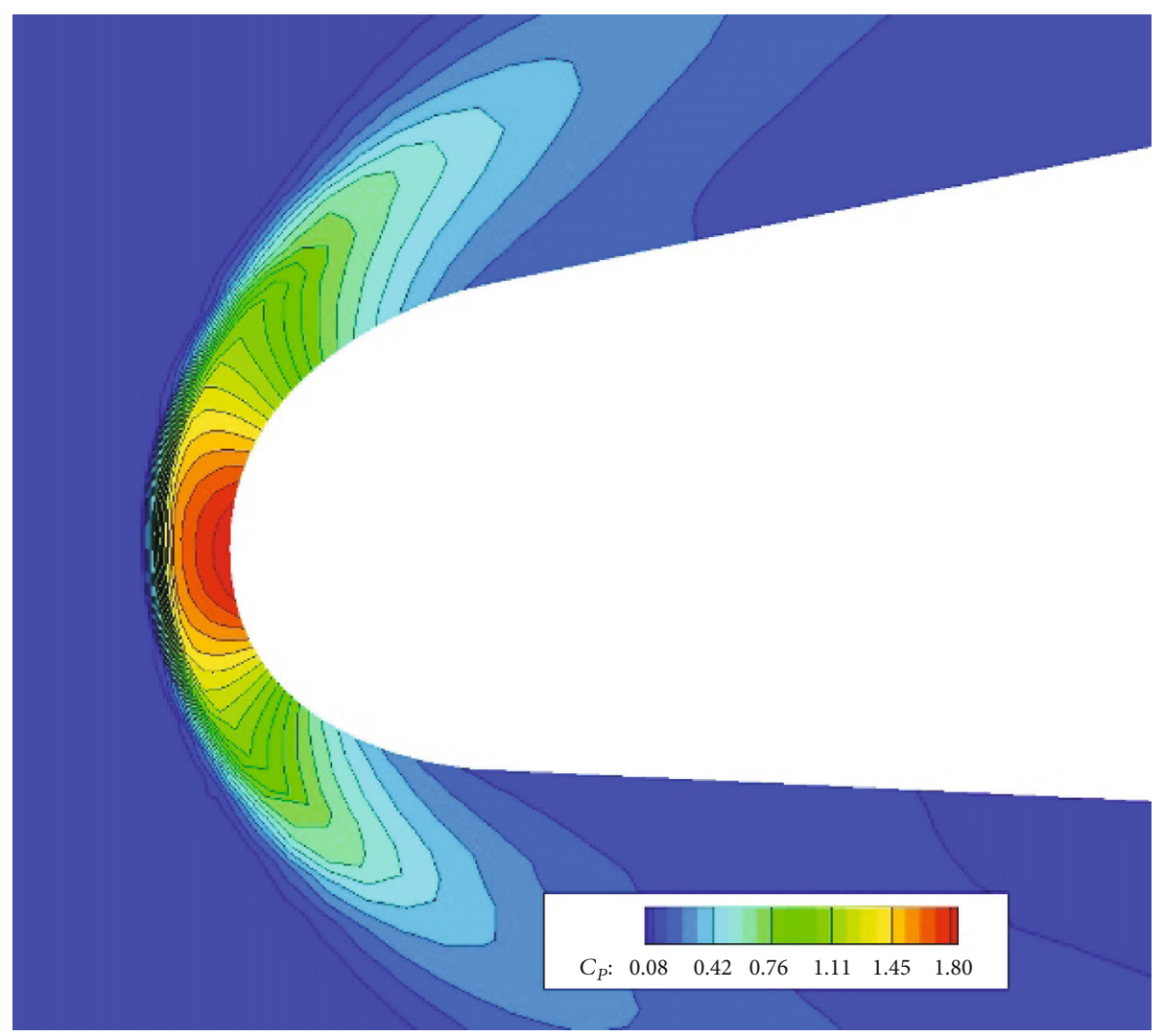

(d)

Figure 13: Contour of $C_{P}$ on the central plane of the blunted waveriders: (a) WR1-G ${ }^{0}$; (b) WR1-G ${ }^{2}$; (c) WR2-G ${ }^{0}$; (d) WR2-G ${ }^{2}$. 

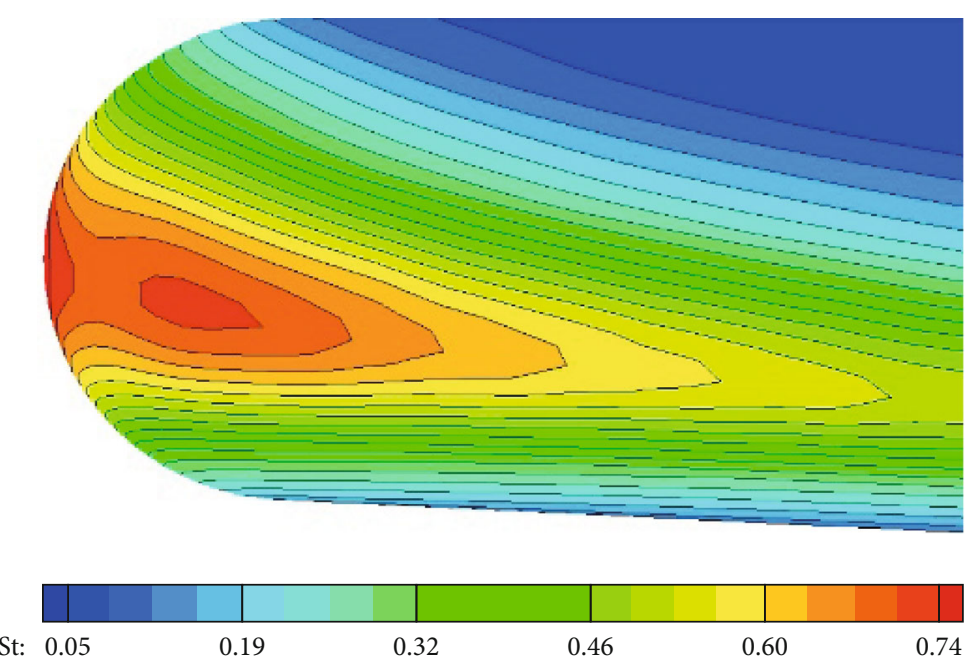

(a)
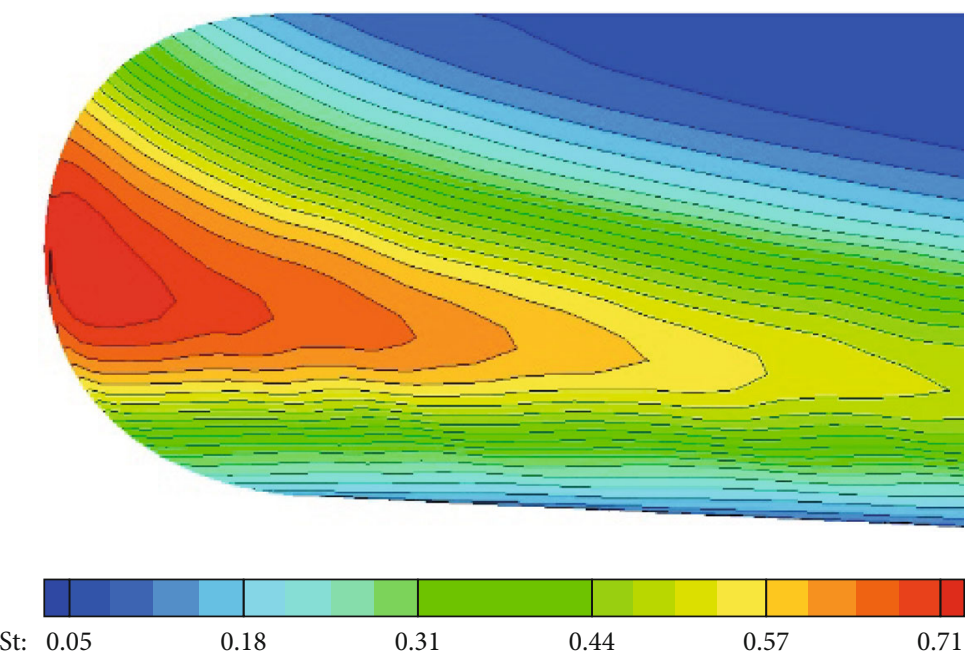

(b)
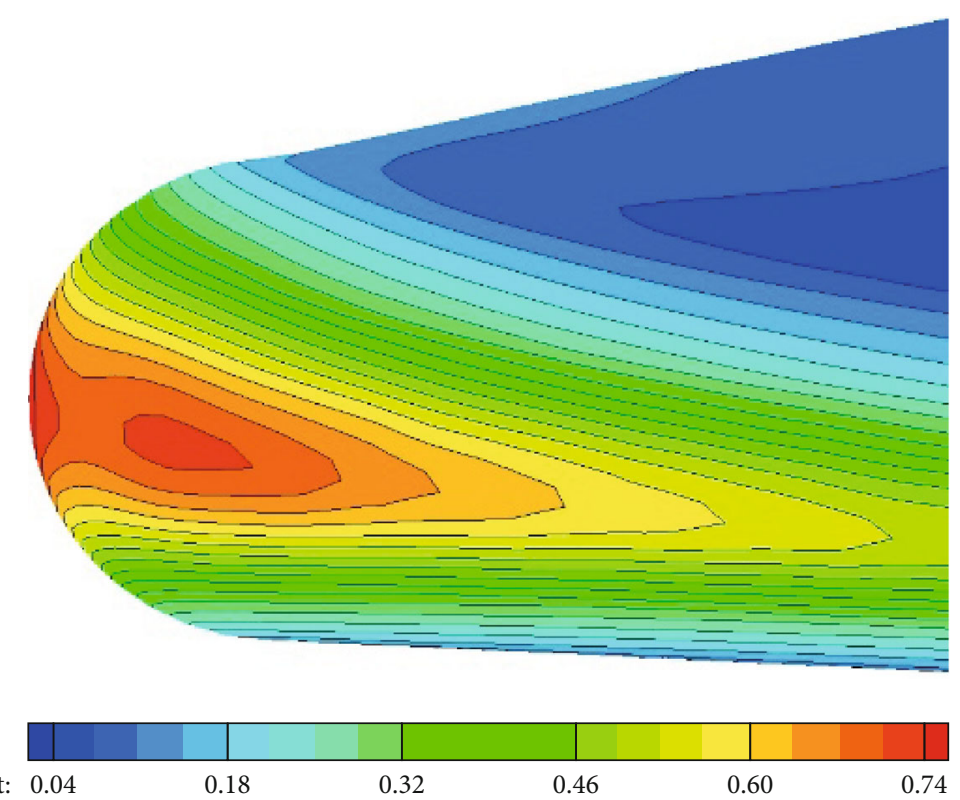

(c)

Figure 14: Continued. 


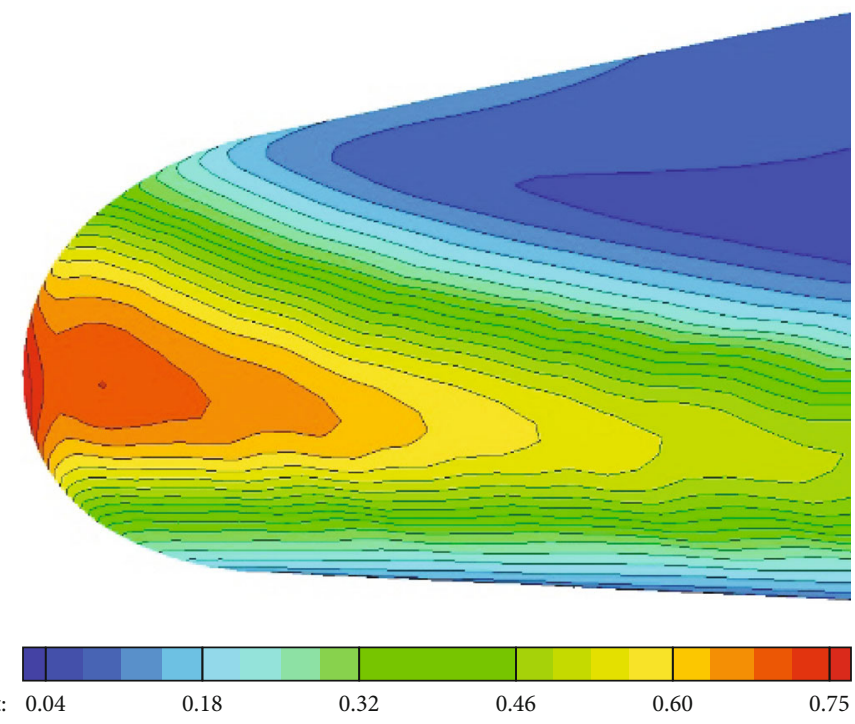

(d)

FIGURE 14: Contour of St around the head of blunted waveriders: (a) WR1-G ; (b) WR1-G²; (c) WR2-G ; (d) WR2-G .

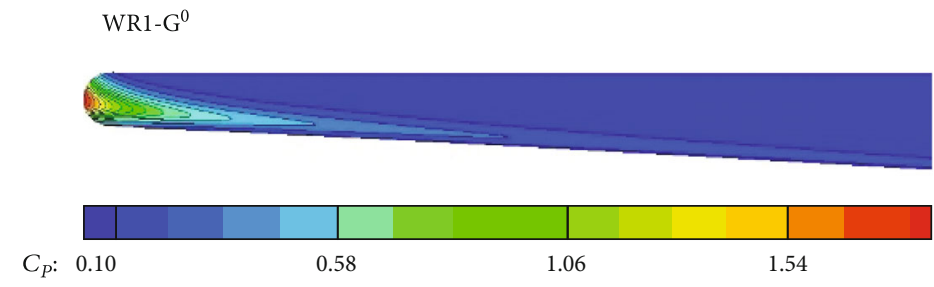

WR1-G

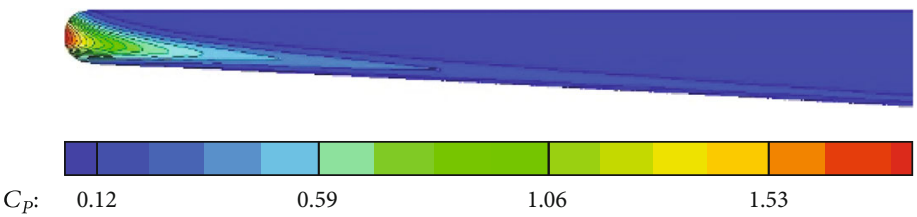

(a)

WR1-G ${ }^{0}$

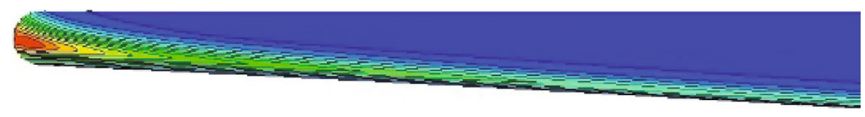

St: 0.06

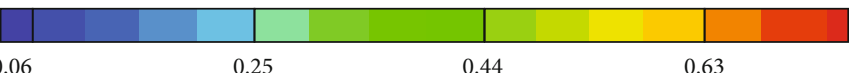

WR1-G ${ }^{2}$

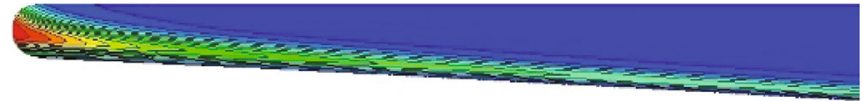

St: 0.06

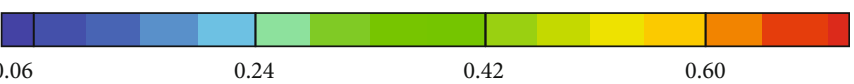

(b)

FIGURE 15: Contours of surface characteristics alongside leading edges of WR1-G ${ }^{0}$ and WR1-G ${ }^{2}$ : (a) contours of $C_{P}$; (b) contours of St. 

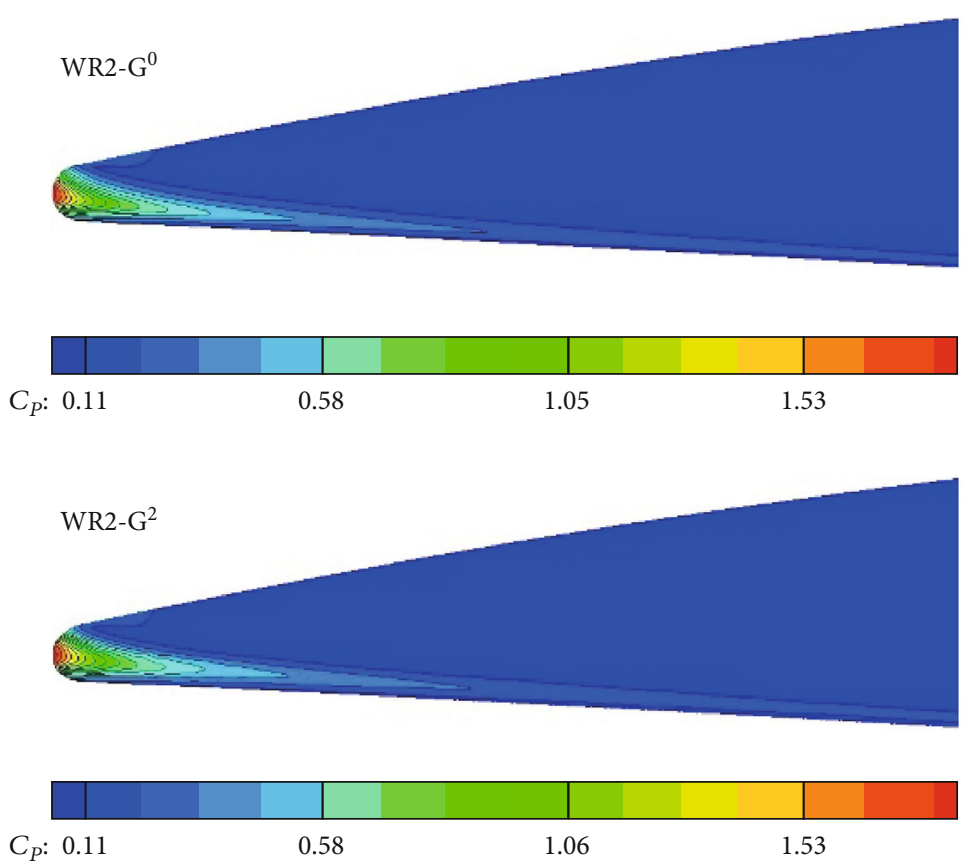

(a)
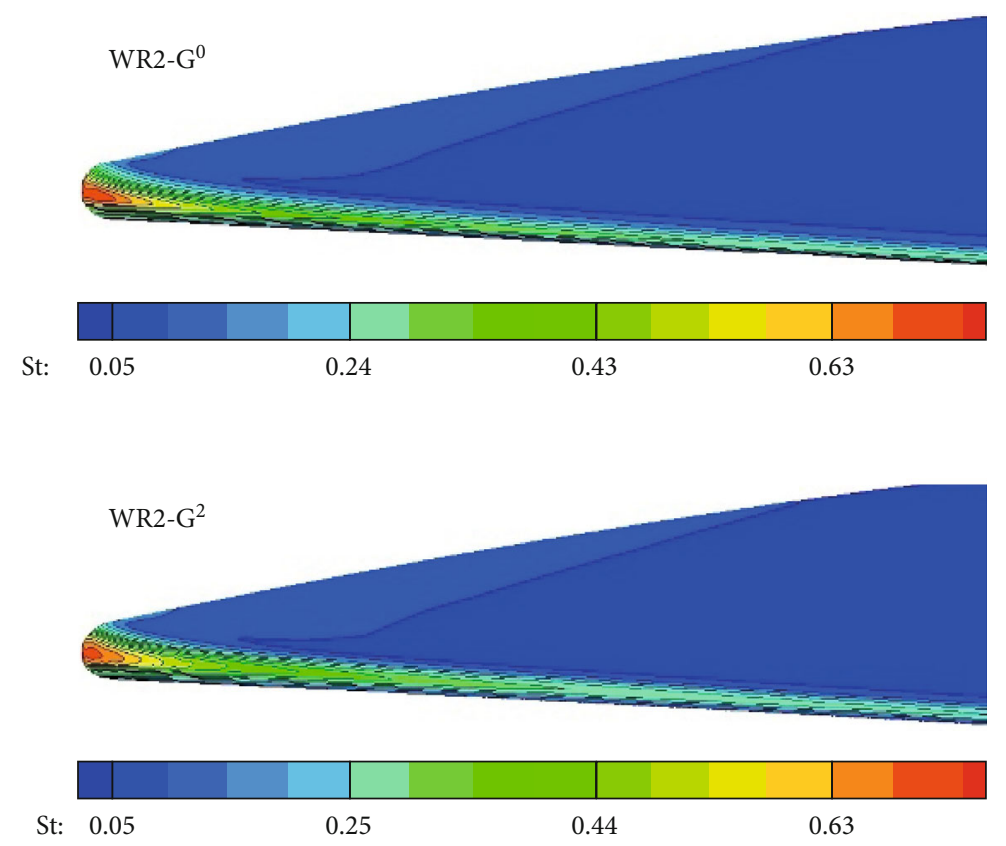

(b)

Figure 16: Contours of surface characteristics alongside leading edges of WR2-G ${ }^{0}$ and WR2-G ${ }^{2}$ : (a) contours of $C_{P}$; (b) contours of St.

4.1. Comparison of Geometric Characteristics. Table 4 gives an overall picture of geometric characteristics of the two original sharp waveriders and the four blunt waveriders, including the total surface area $S$, the area of the base surface $S_{B}$, the total volume $V$, and the available volume $V_{A}$. The available volume corresponds to the inner region that has a distance larger than $25 \mathrm{~mm}$ from the nearest upper and lower surfaces. It shows that the change of the upper surface has a bigger impact on the area of the base surface and the total volume than the total surface area, while the impact on the available volume can be reduced to a negligible level by the design of the upper surface. Besides, owing to the control of blunting parameters, there is nearly no difference on the geometric characteristics between the waveriders blunted by two blunting methods.

The blunt curve on the central plane is observed for further comparison. For the WR1 configurations, the blunting curves from the $G^{0}$ and $G^{2}$ methods are similar; a relatively large deviation is also found on the upper curves, which is depicted in Figure 11(a). When it comes to the WR2 configurations, there is an apparent discrepancy between the two blunting curves. In Figure 11(b), the curve 


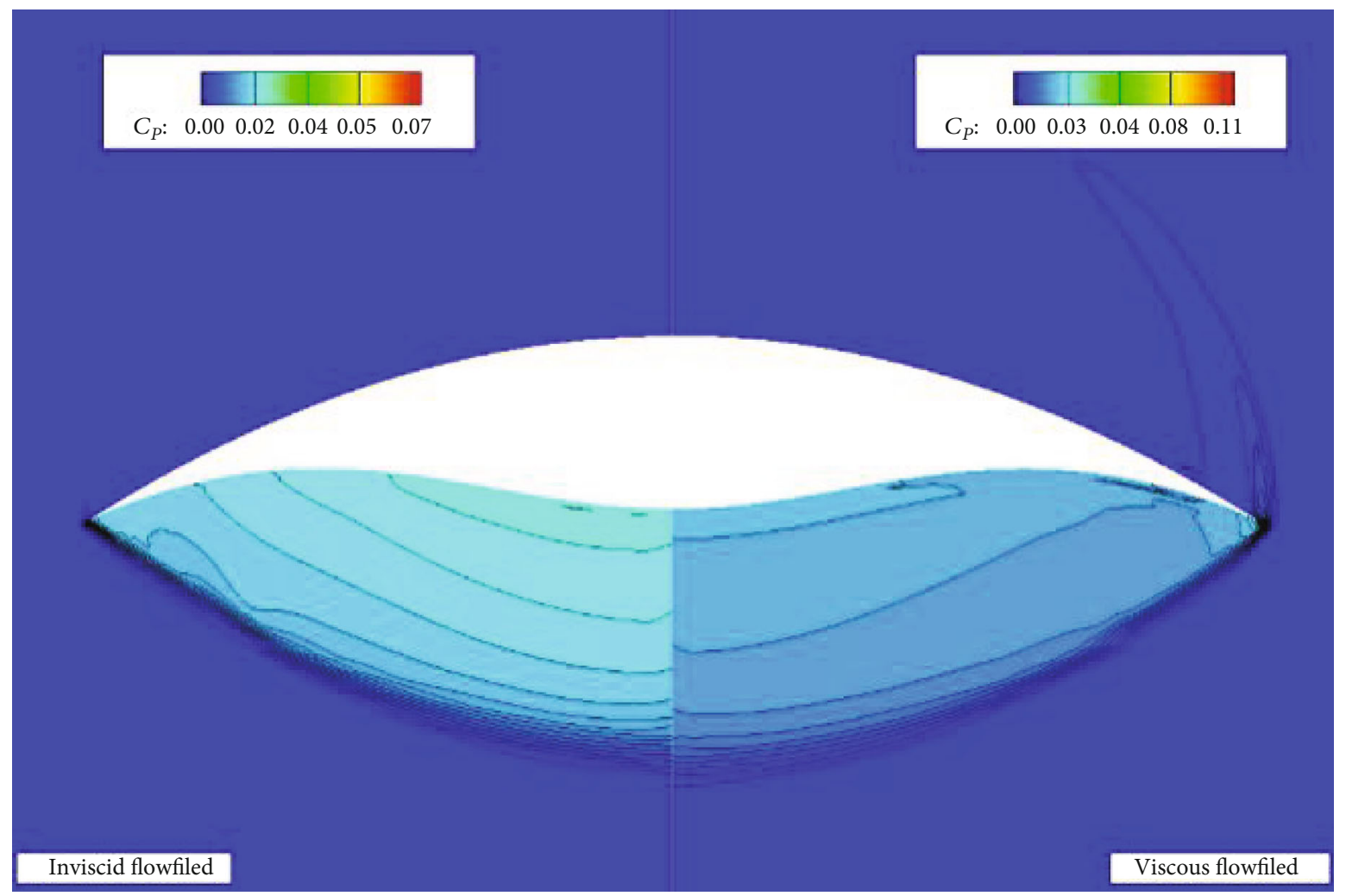

(a)

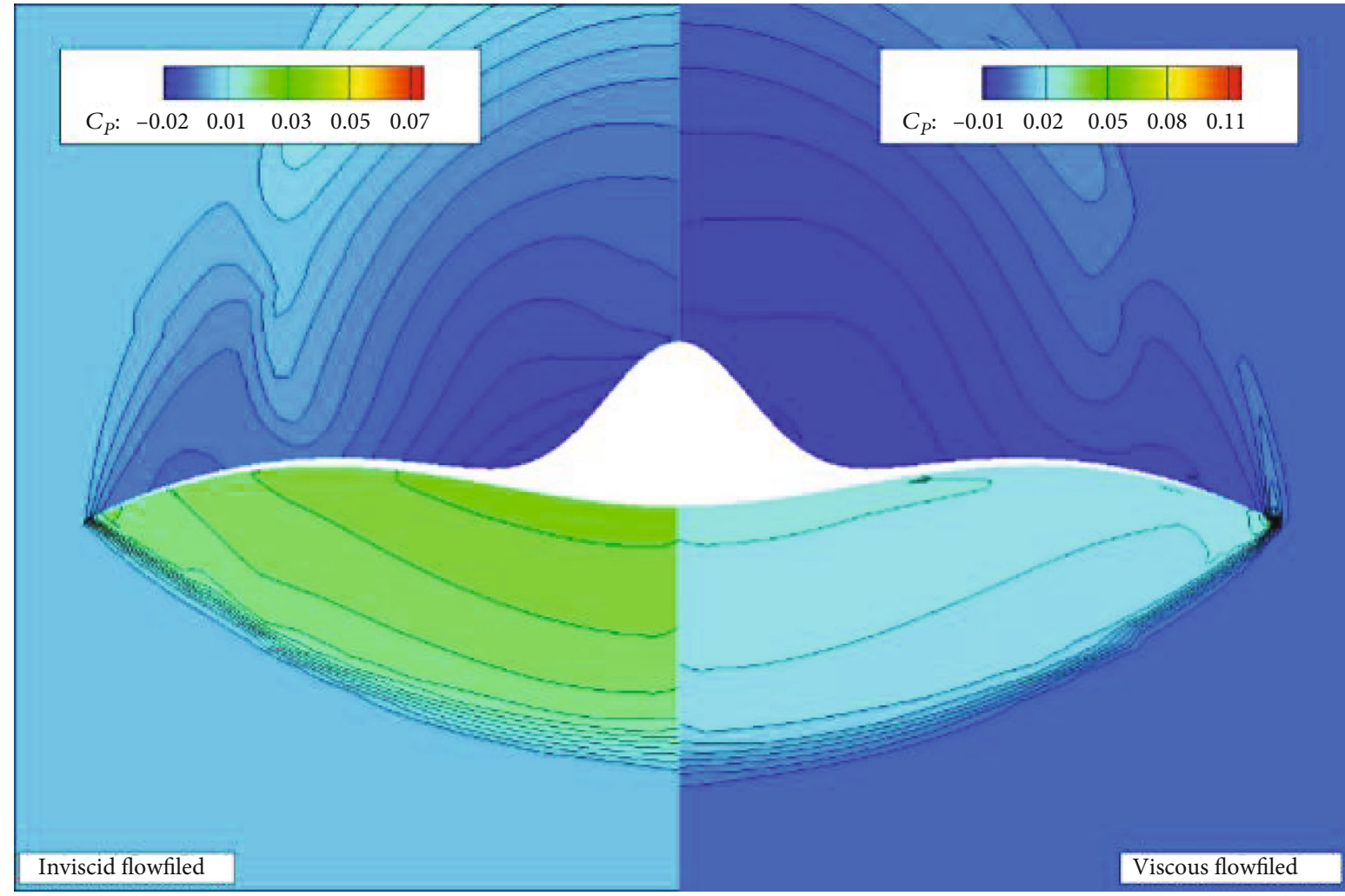

(b)

Figure 17: Continued. 


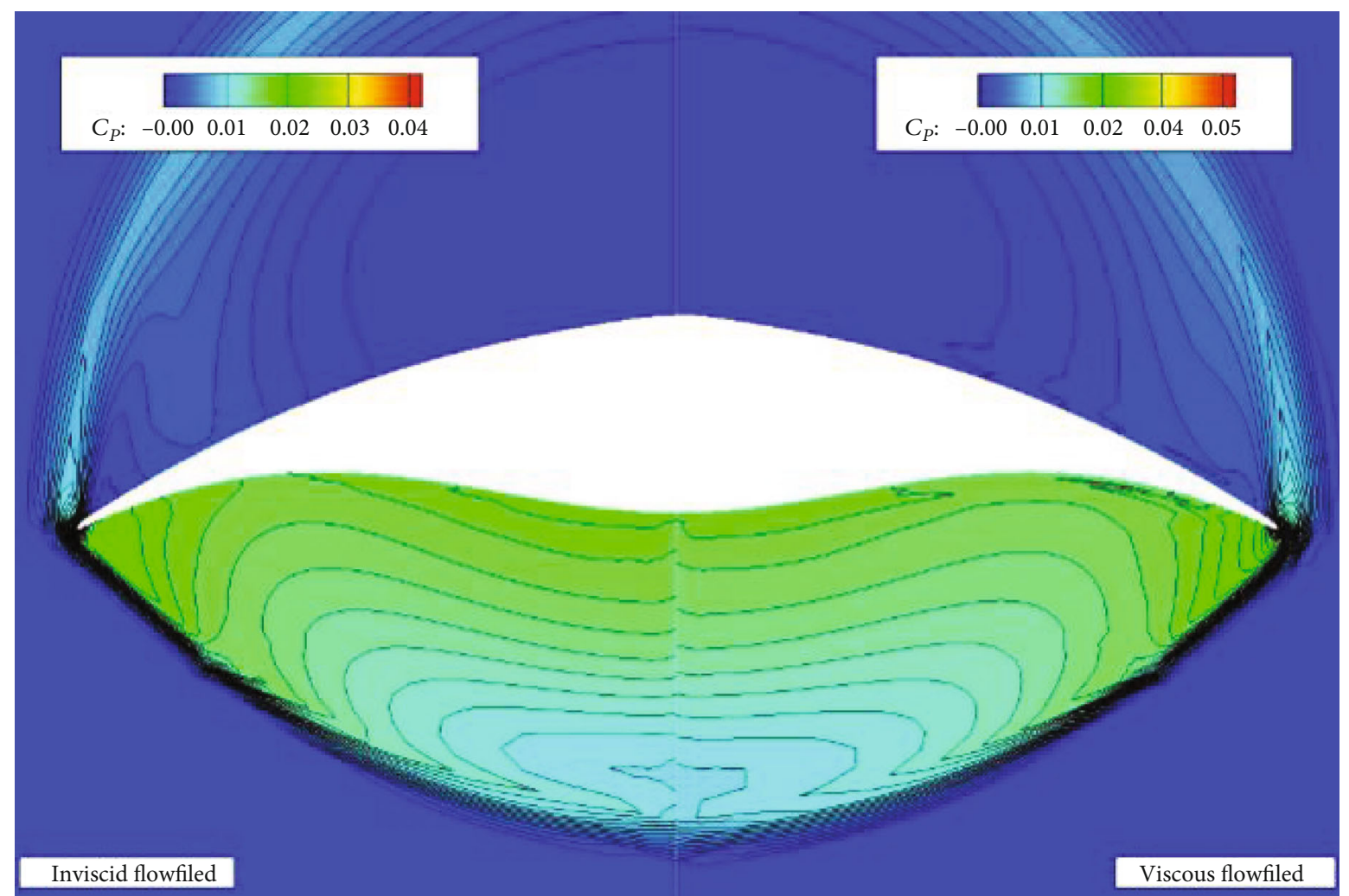

(c)

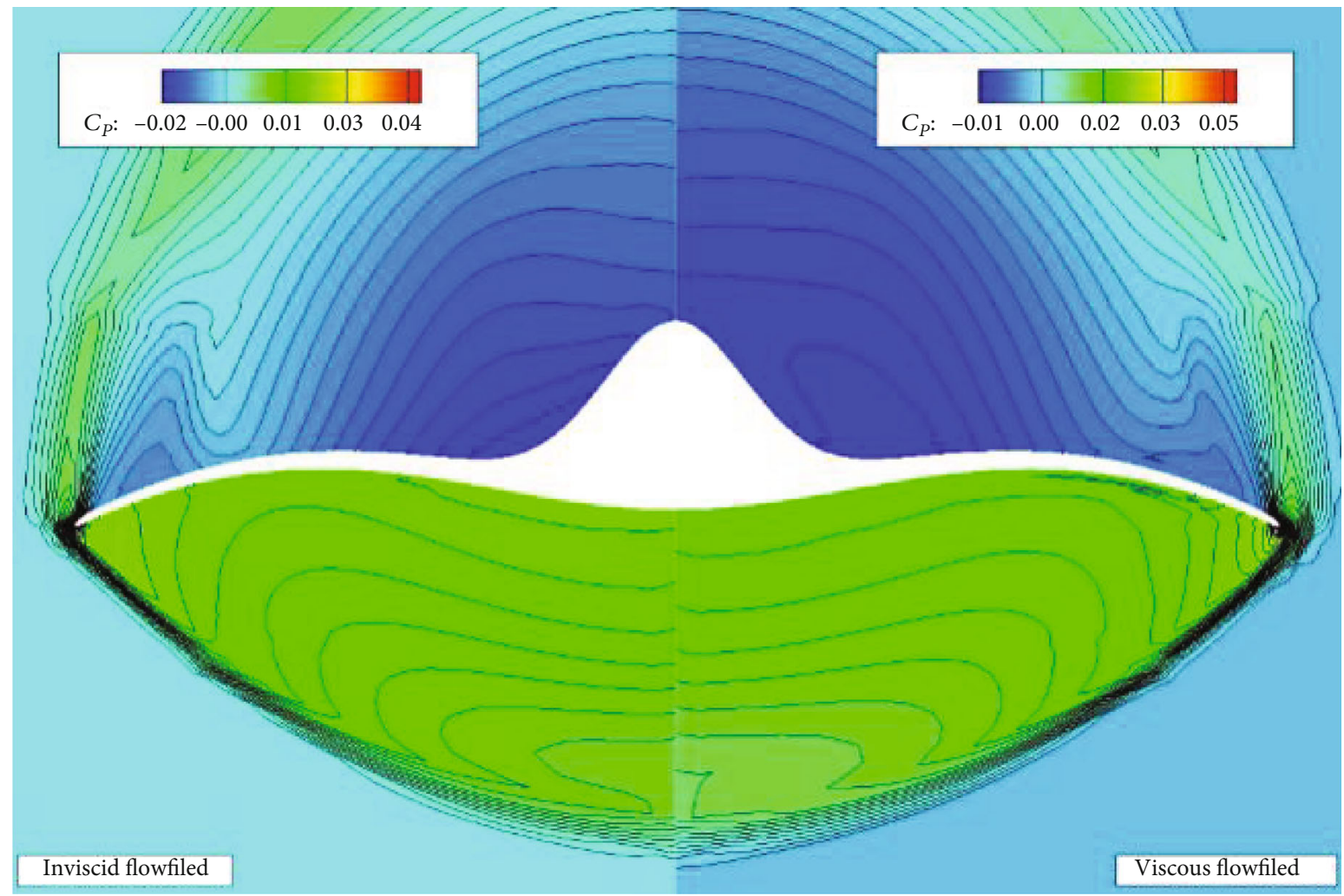

(d)

Figure 17: Continued. 


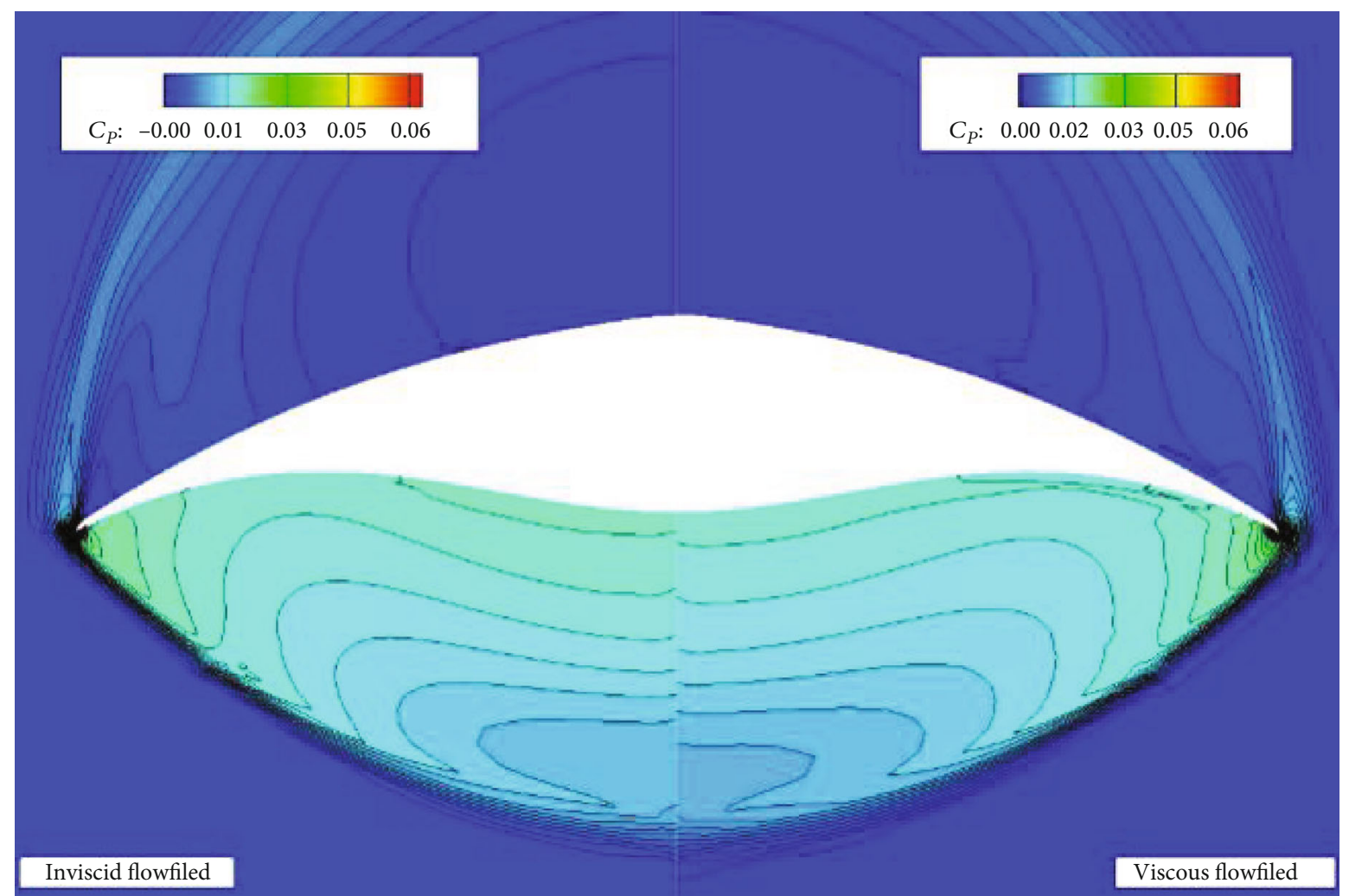

(e)

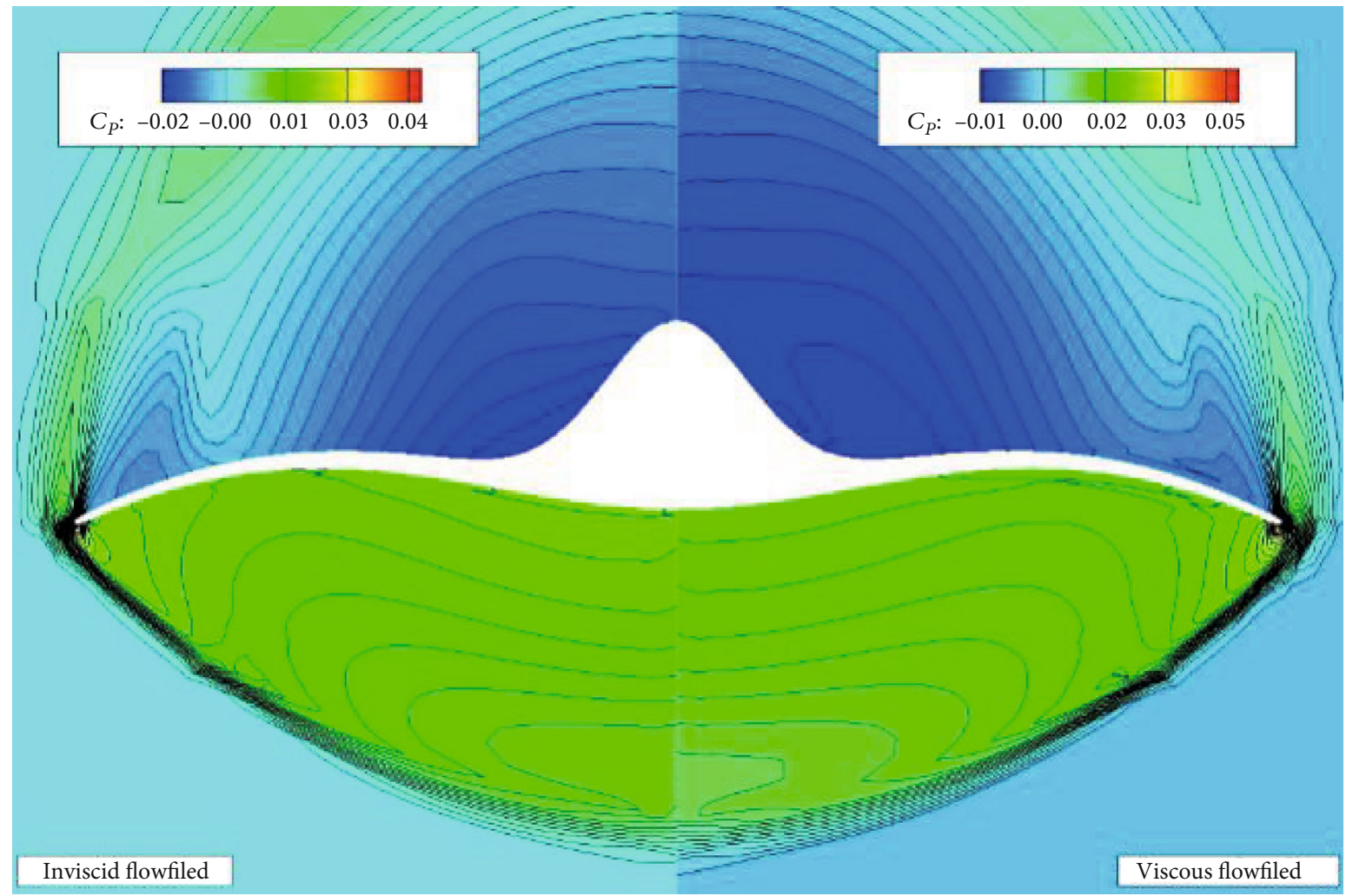

(f)

FIGURE 17: Contours of $C_{P}$ on the base plane of waveriders: (a) WR1; (b) WR2; (c) WR1-G ; (d) WR1-G ; (e) WR1-G ${ }^{2}$; (f) WR2-G². 
generated by the $\mathrm{G}^{2}$ method is lower than its counterpart and shows a smoother connection with the base geometry.

4.2. Comparison of Flow Characteristics. Table 5 gives the overall aerodynamic characteristics of all six waveriders, including the drag coefficient $C_{D}$, the lift coefficient $C_{L}$, and the lift-to-drag ratio $L / D$. Note that both the viscous and inviscid results are listed in Table 5. It is found that the viscosity has large influence on the aerodynamic characteristics of waverider, as the drag coefficient increases greatly after adding the viscosity. Meanwhile, the impact of bluntness is also considerable. However, the aerodynamic difference of two blunting methods is negligible, as the four blunted waveriders have the same distribution of bluntness alongside the leading edge.

Figure 12 compares the surface characteristics on the central blunting curve between two blunting methods. For the $G^{0}$ method, the distributions of $C_{P}$ and St are nearly identical for the upper part and the lower part of the central blunting curves, which corresponds to the line of $x \leq 0 \mathrm{~mm}$ in Figure 12. This is because of the symmetry of the elliptical arc. However, an adverse pressure gradient appears around $x=0 \mathrm{~mm}$ for the WR2-G $\mathrm{G}^{0}$ configuration, which corresponds to the geometric discontinuity in Figure 11(b). Owing to the geometric simplicity of the two WR1 configurations, there is almost no fluctuation of surface characteristics for both the WR1-G $\mathrm{G}^{0}$ and WR1-G $\mathrm{G}^{2}$ configurations. As there is asymmetry between the upper and the lower part of the central blunting curves, the distributions of $C_{P}$ and $S t$ are separated for the WR1-G ${ }^{2}$ and WR2-G ${ }^{2}$ configurations. And all the distributions on the WR1-G and WR2-G ${ }^{2}$ configurations show the smooth transition from the blunted part to the base geometry.

Figure 13 illustrates the contour of $C_{P}$ on the central plane, and no significant difference is found between the two methods. In Figure 14, the contours of St around the head of the blunted waveriders are presented. For the configurations blunted by the $\mathrm{G}^{0}$ method, there exist second peaks of $S t$ besides the stagnation point, which inflects the geometric protrusion corresponding to these peaks. On the contrary, the distributions of heat flux are more concentrated for the WR1-G ${ }^{2}$ and WR2-G ${ }^{2}$ configurations.

Figures 15 and 16 illustrate the contours of surface characteristics alongside the leading edge. It can be observed that both $C_{P}$ and $S t$ decrease alongside the leading edge to the downstream. However, there is no significant difference between geometries blunted by the two methods. When compared to the contours of $C_{P}$, St shows a smoother decrease because of the design of the blunt radius.

Figure 17 presents both the inviscid and viscous contours of $C_{P}$ at the base plane of waveriders. As shown in Figures 17(a) and 17(b), the high-pressure flow is restricted under the lower surface and no flow leaks in the inviscid calculation, which indicates that the design procedure of the lower surface is valid under the design condition. However, the high-pressure air leaks to the upper surface when the viscosity is considered. When it comes the leading-edge bluntness, it has a more significant influence to the flow field of waverider than the viscosity, as the leak is much larger than in Figures 17(a) and 17(b). The influence of the blunting method is relatively small when compared with the bluntness and the viscosity. The waveriders blunted by the two methods have similar shape of shock wave and leak of flow.

\section{Conclusions}

A parametric method for blunting the three-dimensional hypersonic waverider is proposed in this paper. At the theoretical level, the proposed method satisfies the needs of setting a leading-edge blunt radius, achieving second-order geometric continuity, and realizing the parametric design. From the numerical investigation, the new method shows no inferior performance compared with the comparable method, while having a better geometric continuity and a higher degree of freedom. The practical design of the waverider is demanding on this method, as the upper surface has variable geometric characteristic alongside the leading edge. Nevertheless, it is also found that the geometric continuity has little influence on the overall aerodynamic performances when the blunting parameters are fixed. And the impact of geometric continuity on the flow transition needs further study.

\section{Data Availability}

The data used to support the findings of this study are included within the article.

\section{Conflicts of Interest}

The authors declare that there is no conflict of interest regarding the publication of this paper.

\section{Acknowledgments}

The authors express their gratitude for the financial support provided by the National Natural Science Foundation of China [grant number 11702322], the Hunan Province Natural Science Foundation [grant number 2020JJ4656] and the Scientific Research Project of NUDT [grant number ZK20-43].

\section{References}

[1] D. A. Lunan, "Waverider, a revised chronology," in 20th AIAA International Space Planes and Hypersonic Systems and Technologies Conference, Glasgow, Scotland, July 2015.

[2] T. R. F. Nonweiler, "Aerodynamic problems of manned space vehicles," Journal of the Roy Aeronautical Society, vol. 63, no. 585, pp. 521-528, 1959.

[3] I. I. Mazhul and R. D. Rakhcimov, "Hypersonic power-law shaped waveriders in off-design regimes," Journal of Aircraft, vol. 41, no. 4, pp. 839-845, 2004.

[4] J. G. Jones, K. C. Moore, J. Pike, and P. L. Roe, "A method for designing lifting configurations for high supersonic speeds, using axisymmetric flow fields," Ingenieur-Archiv, vol. 37, no. 1, pp. 56-72, 1968.

[5] M. L. Rasmussen, "Waverider configurations derived from inclined circular and elliptic cones," Journal of Spacecraft and Rockets, vol. 17, no. 6, pp. 537-545, 1980. 
[6] M. L. Rasmussen and L. W. Clement, "Cone-derived waveriders with longitudinal curvature," Journal of Spacecraft and Rockets, vol. 23, no. 5, pp. 461-469, 1986.

[7] K. Cui, D. Zhao, and G. Yang, "Waverider configurations derived from general conical flowfields," Acta Mech. Sin., vol. 23, no. 3, pp. 247-255, 2007.

[8] F. Ding, J. Liu, C. Shen, and W. Huang, "Novel approach for design of a waverider vehicle generated from axisymmetric supersonic flows past a pointed von Karman ogive," Aerospace Science and Technology, vol. 42, pp. 297-308, 2015.

[9] Y. P. Goonko, I. I. Mazhul, and G. N. Markelov, "Convergentflow-derived waveriders," Journal of Aircraft, vol. 37, no. 4, pp. 647-654, 2000.

[10] N. Takashima and M. J. Lewis, "Wedge-cone waverider configuration for engine-airframe interaction," Journal of Aircraft, vol. 32, no. 5, pp. 1142-1144, 1995.

[11] C. Liu, P. Bai, Y. Chen, and C. Ji, "Rapid design and multiobject optimization for waverider form 3D flow," Journal of Astronautics, vol. 37, p. 535, 2016.

[12] H. Sobieczky, F. Dougherty, and K. Jones, Hypersonic Waverider Design from Given Shock Waves, University of Maryland, USA, 1990.

[13] P. Rodi, "The osculating flowfield method of waverider geometry generation," in 43rd AIAA Aerospace Sciences Meeting and Exhibit, Reno, Nevada, January 2005.

[14] X. He, J. Le, and Y. Wu, "Design of a curved cone derived waverider forebody," in 16th AIAA/DLR/DGLR International Space Planes and Hypersonic Systems and Technologies Conference, Bremen, Germany, October 2009.

[15] X. He, J. Le, Z. Zhou, P. Mao, and Y. Wu, "Osculating inward turning cone waverider/inlet (OICWI) design methods and experimental study," in 18th AIAA/3AF International Space Planes and Hypersonic Systems and Technologies Conference, Tours, France, September 2012.

[16] Z. Lyu, J. Wang, Y. Wu, and K. Cheng, "Design and analysis of multistage compression cone-derived waverider configuration," Journal of Astronautic, vol. 36, p. 518, 2015.

[17] K. Kontogiannis, A. Sóbester, and N. Taylor, "Efficient parameterization of waverider geometries," Journal of Aircraft, vol. 54, no. 3, pp. 890-901, 2017.

[18] K. Kontogiannis, A. Sóbester, and N. Taylor, "Waverider design based on three-dimensional leading edge shapes," Journal of Aircraft, vol. 54, no. 5, pp. 2010-2012, 2017.

[19] B. S. Kim, M. L. Rasmussen, and M. C. Jischke, "Optimization of waverider configurations generated from axisymmetricconical flows," Journal of Spacecraft and Rockets, vol. 20, no. 5, pp. 461-469, 1983.

[20] K. G. Bowcutt, J. D. Anderson, and D. Capriotti, "Viscous optimized hypersonic waveriders," in 25th AIAA Aerospace Sciences Meeting, Reno, NV,USA, March 1987.

[21] N. Takashima and M. Lewis, "Powered hypersonic waverider vehicles for optimization with mission-oriented constraints," in 33rd Aerospace Sciences Meeting and Exhibit, Reno, NV, USA, January 1995.

[22] M. Lobbia and K. Suzuki, "Design and analysis of payloadoptimized waveriders," in 10th AIAA/NAL-NASDA-ISAS International Space Planes and Hypersonic Systems and Technologies Conference, Kyoto, Japan, April 2001.

[23] X. Chen, Z. Hou, H. Lietang, and J. Liu, "Multi-object optimization of waverider generated from conical flow and osculating cone," in 46th AIAA Aerospace Sciences Meeting and Exhibit, Reno, Nevada, January 2008.

[24] S. Li, S. Luo, W. Huang, and Z. Wang, "Influence of the connection section on the aerodynamic performance of the tandem waverider in a wide-speed range," Aerospace Science and Technology, vol. 30, no. 1, pp. 50-65, 2013.

[25] Y. Takama, "Practical waverider with outer wings for the improvement of low-speed aerodynamic performance," in 17th AIAA International Space Planes and Hypersonic Systems and Technologies Conference, San Francisco, California, April 2011.

[26] F. Ding, J. Liu, W. Huang, C. Peng, and S. Chen, “An airframe/inlet integrated full-waverider vehicle design using as upgraded aerodynamic method," Aeronautical Journal, vol. 123, no. 1266, pp. 1135-1169, 2019.

[27] S. Walker, M. Tang, S. Morris, and C. Mamplata, "Falcon HTV-3X - a reusable hypersonic test bed," in 15th AIAA International Space Planes and Hypersonic Systems and Technologies Conference, Dayton, Ohio, April 2008.

[28] T. Smith, K. Bowcutt, J. Selmon et al., "HIFiRE 4: a low-cost aerodynamics, stability, and control hypersonic flight experiment," in 17th AIAA International Space Planes and Hypersonic Systems and Technologies Conference, San Francisco, California, April 2011.

[29] G. Pezzella, M. Marini, M. Cicala, A. Vitale, T. Langener, and J. Steelant, "Aerodynamic characterization of HEXAFLY scramjet propelled hypersonic vehicle," in 32nd AIAA Applied Aerodynamics Conference, Atlanta, GA, USA, 2014.

[30] D. Stevens, "Practical considerations in waverider applications," in Guidance, Navigation and Control Conference, Hilton Head Island, SC, USA, August 1992.

[31] D. J. Tincher and D. W. Burnett, "Hypersonic waverider test vehicle - a logical next step," Journal of Spacecraft and Rockets, vol. 31, no. 3, pp. 392-399, 1994.

[32] P. E. Rodi, "Integration of optimized leading edge geometries onto waverider configurations," in 53rd AIAA Aerospace Sciences Meeting, Kissimmee, Florida, January 2015.

[33] K. Kontogiannis, A. Cerminara, N. J. Taylor, A. Sobester, and N. Sandham, "Parametric geometry models for hypersonic aircraft components: blunt leading edges," in 20th AIAA International Space Planes and Hypersonic Systems and Technologies Conference, Glasgow, Scotland, July 2015.

[34] X. Chen, Z. Hou, J. Liu, and X. Gao, "Bluntness impact on performance of waverider," Computers and Fluids, vol. 48, no. 1, pp. 30-43, 2011.

[35] S. P. Mahulikar, "Theoretical aerothermal concepts for configuration design of hypersonic vehicles," Aerospace Science and Technology, vol. 9, no. 8, pp. 681-685, 2005.

[36] A. Viviani and G. Pezzella, Aerodynamic and Aerothermodynamic Analysis of Space Mission Vehicles, Springer International Publishing, Cham, 2015.

[37] S. Li, Z. Wang, W. Huang, S. Xu, and L. Yan, "Aerodynamic performance investigation on waverider with variable blunt radius in hypersonic flows," Acta Astronautica, vol. 137, pp. 362-372, 2017.

[38] C. de Boor, K. Höllig, and M. Sabin, "High accuracy geometric Hermite interpolation," Computer Aided Geometric Design, vol. 4, no. 4, pp. 269-278, 1987.

[39] D. Liu, "The shape control of the parametric cubic curve segment and the Bézier cubic curve," Acta Math. Appl. Sin., vol. 4, no. 2, pp. 158-165, 1981. 
[40] S. Li, The Flow Characteristics for the Typical Model in Hypersonic Flows, National Defence Industry Press, Beijing, 2007.

[41] F. Ding, C. Shen, J. Liu, and W. Huang, "Influence of surface pressure distribution of basic flow field on shape and performance of waverider," Acta Astronautica, vol. 108, pp. 62-78, 2015.

[42] X. Sun, Z. Guo, W. Huang, S. Li, and L. Yan, "Drag and heat reduction mechanism induced by a combinational novel cavity and counterflowing jet concept in hypersonic flows," Acta Astronautica, vol. 126, pp. 109-119, 2016. 